EHINOKOKOZES DIAGNOSTIKAS PILNVEIDOŠANA, IZMANTOJOT ETIOLOG̦ISKUS, BIOĶİMISKUS, IMUNOLOĢISKUS UN IMŪNĢENĒTISKUS MARĶIERUS, UN RISKA FAKTORU APZINĀŠANA LATVIJĀ

Promocijas darba kopsavilkums medicinas doktora zinātniskā grāda iegūšanai Specialitāte - infektoloǵija 


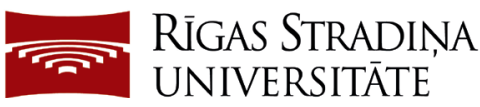

Sniedze Laivacuma

\section{EHINOKOKOZES DIAGNOSTIKAS} PILNVEIDOŠANA, IZMANTOJOT ETIOLOG̣ISKUS, BIOĶİMISKUS, IMUNOLOGISKUS UN

IMŪNĢENĒTISKUS MARĶIERUS, UN RISKA FAKTORU APZINĀŠANA LATVIJĀ

Promocijas darba kopsavilkums medicīnas doktora zinātniskā grāda iegūšanai

Specialitāte - infektologija

Rīga, 2019 
Promocijas darbs izstrādāts Rīgas Stradiņa universitātē.

Darba zinātniskie vadītāji:

Dr. habil. med. profesore Ludmila Vīksna,

Rīgas Stradiṇa universitāte, Latvija

Dr. sc. soc. docents Andrejs Ivanovs,

Rīgas Stradiṇa universitāte, Latvija

Oficiālie recenzenti:

Dr. med. asociētā profesore Dace Zavadska,

Rīgas Stradiņa universitāte, Latvija

Dr. med. profesors Saulius Čaplinskas,

Mīkola Romera universitāte, Infekciju slimību un AIDS centrs, Lietuva Dr. biol. Muza Kirjušina,

Daugavpils Universitāte, Dzīvības zinātṇu un tehnolog̣iju institūts, Latvija

Promocijas darba aizstāvēšana notiks 2019. gada 2. decembrī plkst.15.00 Rīgas Stradiṇa universitātes Medicīnas promocijas padomes atklātā sēdē Rīgā, Dzirciema ielā 16, Hipokrāta auditorijā.

Ar promocijas darbu var iepazīties RSU bibliotēkā un RSU tīmekḷa vietnē: www.rsu.lv.

Promocijas padomes sekretārs:

Dr. med. profesore Juta Kroiča 


\section{SATURA RĀDĪTĀJS}

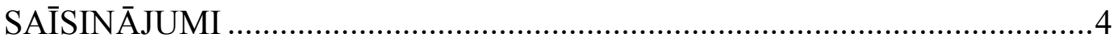

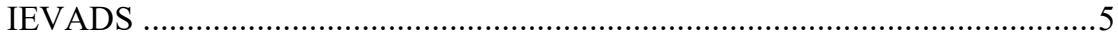

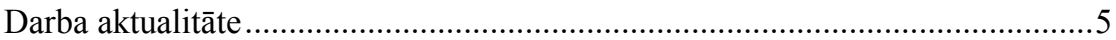

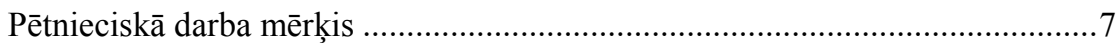

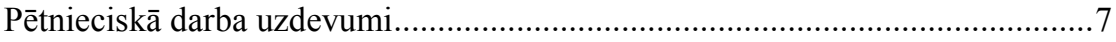

Pētnieciskā darba hipotēzes .......................................................................

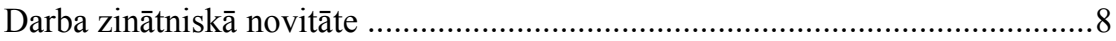

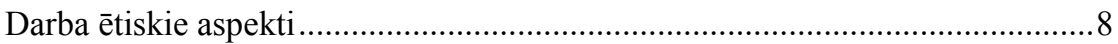

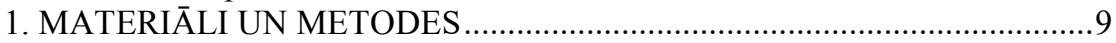

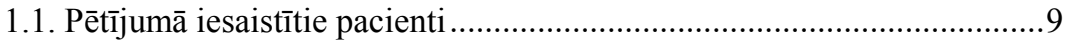

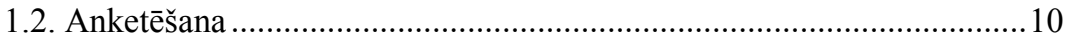

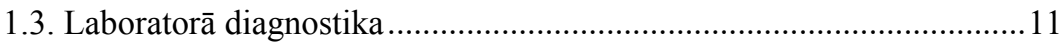

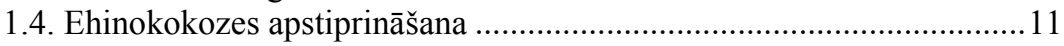

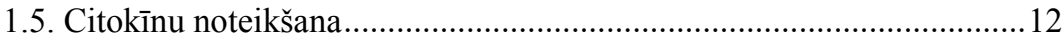

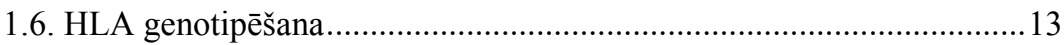

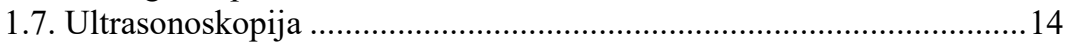

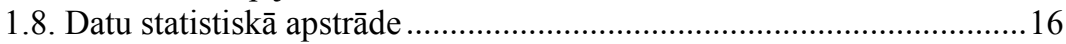

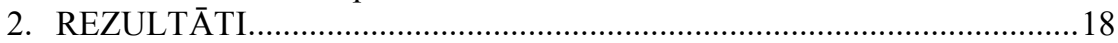

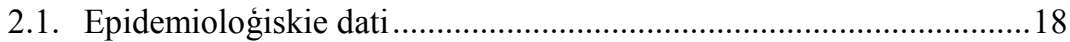

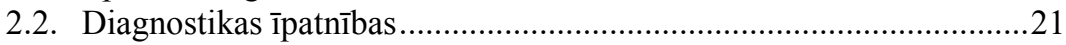

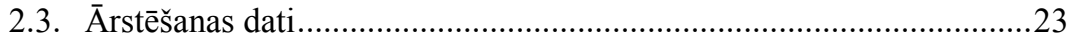

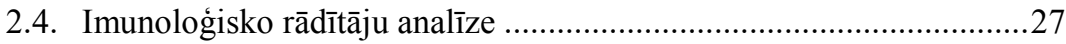

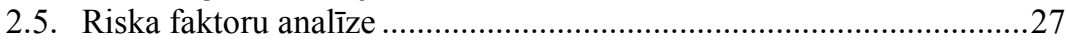

2.5.1. Epidemioloğiskie riska faktori .............................................27

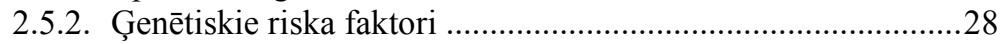

2.6. Pètījumā iekḷauto pacientu mirstība ....................................................33

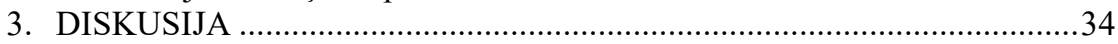

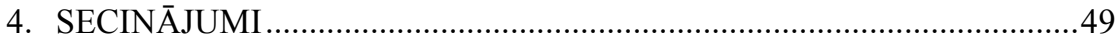

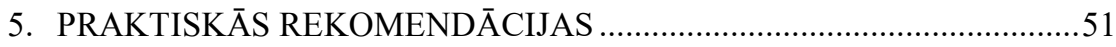

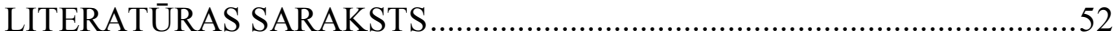

PUBLIKĀCIJAS UN PREZENTĀCIJAS PAR PĒTİJUMA TĒMU...............61

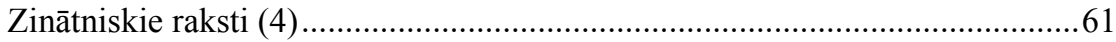

Tēzes un prezentācijas starptautiskās konferencēs (5) ...................................61

Tēzes un uzstāšanās Latvijas mēroga konferencēs (6)......................................62

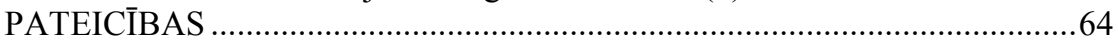




\section{SAĪSINĀJUMI}

BMZ - benzimidazoli

CE - cistiskā ehinokokoze

ECDC - Eiropas Slimību kontroles un profilakses centrs (no angḷu val.:

European Centre of Disease Control and Prevention)

GGT - $\gamma$-glutamiltransferāze

HLA - cilvēka leikocitārais antigēns (no angḷu val.: human leucocyte antigene)

IL - interleikīns

$\mathrm{M}$ - vidējais aritmētiskais (no anglu val.: mean)

max - maksimālā vērtība

$\mathrm{Me}$ - mediāna

Min - minimālā vērtība

$\mathrm{n}$ - pacientu skaits

OR - izredžu attiecība (no angl̦u val.: Odds Ratio)

p - p-vērtība, varbūtība, būtiskuma līmenis

PVO - Pasaules Veselības organizācija

$\mathrm{r}$ - korelācijas koeficients

SD - standartnovirze (no angḷu val.: standard deviation)

SF - sārmainā fosfatāze

TI - 95\% ticamības intervāls

USG - ultrasonogrāfija

$\mathrm{Q}_{1}$ - pirmā kvartīle

$\mathrm{Q}_{3}$ - trešā kvartīle 


\section{IEVADS}

\section{Darba aktualitāte}

Echinococcus infekcija ir parazitoze, kas izplatīta visā pasaulē. Tradicionāli uzskata, ka tā vairāk skar Āzijas valstis, galvenokārt Ķ̄nnu, kā arī Eiropas centrālo daļu un atsevišķus reǵionus Dienvidamerikā, bet pēdējos gados veikto pētījumu dati liecina par šîs infekcijas slimības izplatības reǵiona paplašināšanos. Balstoties uz 2003. gadā uzsāktā Eiropas Savienības ehinokokozes monitoringa datiem, aizvien plašākās teritorijās, tai skaitā Eiropas ziemeļu un austrumu rajonos, tiek registrēti saslimšanas gadījumi (Gottstein, 2010; Giraudoux et al., 2010; Soba et al., 2010). Tas arī bija bija iemesls pievērstos ehinokokozes detalizētai izpētei Latvijā.

Slimībai, ko apzīmē ar terminu "ehinokokoze", ir divi varianti: cistiskā ehinokokoze, ko ierosina Echinococcus granulosus, kas no klīniskā viedokḷa ir mazāk agresīvā ehinokokozes forma, jo vairumā gadījumu veido labi norobežotus cistām līdzīgus perēkḷus; savukārt alveolārā ehinokokoze, ko ierosina Echinococcus multilocularis, ir saslimšana, kam raksturīga agresīva klīniskā gaita, kad parazīts veido audzējiem līdzīgus perēkḷus ar infiltratīvu izplatību bojāajajā orgānā. Turklāt E. multilocularis infekcijas gadījumā ir iespējama metastazēšanās, parazītam nokḹstot asins straumē vai žultsceļos, tādējādi radot papildus problēmas. Izšķirir arī policistisko jeb "neotropisko" ehinokokozi, ko ierosina Echinococcus vogeli vai retāk sastopamais Echinococcus oligarthus. Abiem minētajiem ir raksturīga alveolārai ehinokokozei līdzīga, bet mazāk agresīva saslimšana. Šo formu izplatība līdz šim ir reǵistrēta tikai Dienvidamerikas kontinentā. Inficējoties ar parazìtu, galvenokārt tiek skartas aknas, retākos gadījumos iespējama perēkļu veidošanās plaušās, centrālās nervu sistēmas orgānos un kaulos (Eckert et al., 2001). 
Arī mūsdienās ehinokokozes savlaicīga diagnostika un līdz ar to ārstēšana bieži ir novēlota, jo slimībai sākuma posmā nav izteiktas specifiskas klīniskās ainas un nereti diagnoze tiek noteikta, balstoties uz ultrasonoskopijas datiem, kas veikta citu medicīnisku indikāciju sakarā, un tikai pēc tam veikta specifiska serologiiskā analīze. Nereti pacientam jau komplikāciju dēḷ ir radušās sūdzības, kas vedina izdarīt specifiskas antivielu analīzes. Ja ehinokokoze, īpaši alveolārā forma, netiek ārstēta, tad 10 gadu laikā pēc diagnozes noteikšanas $>90 \%$ gadījumu ir letāls iznākums (Kern et al., 2003). Svarīgi atzīmēt, ka ehinokokoze, ja netiek savlaicīgi atklāta un radikāli ārstēta, ir saslimšana, kas norit hroniski un prasa būtiskus finansiālus resursus, jo pretparazitārā terapija pacientiem bieži vien jāsaņem visu mūžu, lai apturētu infekcijas tālāku izplatīšanos (Eckert et al., 2001).

Saslimstība ar ehinokokozi Eiropas valstīs ir variabla, svārstoties 0,1-10/100000 gadījumu robežās (Gottstein, 2010; Giraudoux et al., 2010; Soba et al., 2010). Arī Latvijā katru gadu ir samērā liels pirmreizēji diagnosticētu ehinokokozes gadījumu skaits, neskatoties uz salīdzinoši nelielo iedzīvotāju skaitu. Būtiski, ka Latvija ǵeogrāfiski atrodas blakus endēmiskiem šīs zoonozes rajoniem, piemēram, Krievijai, Baltkrievijai, Polijai, bet mērķtiecīgi pētījumi par saslimstību, riska faktoriem, diagnostiku un ārstēšanu tieši mūsu valstī nav bijuši, nav arī pieejami dati par pacientu dz̄̄ves kvalitāti, ja nav bijusi iespēja parazītu izdalīt radikālā ceḷā ķirurgisiski un ir nepieciešama gadiem ilga medikamentoza terapija.

Literatūrā ir pieejami, bet nepietiekami detalizēti, dati par imunoloǵisko rādīiāju, galvenokārt, IL-4, IL-10, izmantošanu papildus radioloǵiskajām un serologiiskajām diagnostikas metodēm, lai izvērtētu ehinokokozes ārstēšanas efektivitāti un precizētu tās tālāko attīstības taktiku (Nouir et al.,2008; Rigano et al.,1995).

Tādēl ir svarīgi apkopot un analizēt datus par ehinokokozes izplatību un norisi, lai rastu agrīnas diagnostikas un radikālas terapijas iespējas. 


\section{Pētnieciskā darba mērḳis}

Noteikt, apkopot un analizēt ehinokokozes izplatību Latvijā, noskaidrot slimības norisi, pilnveidot diagnostikas un ārstēšanas taktiku un apzināt saslimšanas riska faktorus.

\section{Pētnieciskā darba uzdevumi}

1. Analizēt populācijas datus, lai noskaidrotu ehinokokozes izplatību Latvijas teritorijā.

2. Konstatēt riska faktorus, tai skaitā, imūnğenētiskos, kas veicina inficēšanos ar Echinococcus sp.

3. Analizēt un salīdzināt ultrasonoskopijas un serologiskās izmeklēšanas datus pirms ārstēšanas un noteiktos izvēlētos laika posmos.

4. Prognozēt medikamentozās ārstēšanas efektu, izmantojot imunoloǵiskos rādītājus - IL-4 un IL-10..

5. Apkopot un analizēt iegūtos datus un sagatavot rekomendācijas ārstiem, lai pilnveidotu ehinokokozes diagnostiku un ārstēšanu.

\section{Pētnieciskā darba hipotēzes}

1. Ehinokokozes pacienti ir sastopami gandrīz visā Latvijas teritorijā.

2. Ehinokokozes diagnostika un ārstēšana vairumā gadījumu ir novēlota un to ir iespējams ietekmēt, apzinot riska faktorus, kas ļautu uzlabot slimības profilaksi.

3. Ehinokokozes diagnostiku un novērošanas efektivitāti var uzlabot regulāri veicot radiolog̣iskus un serologiiskus izmeklējumus, kā arī 
nosakot imunologiskus rādītājus (IL-4, IL-10).

4. Imūnǵenētiskie izmeklējumi var atklāt protektīvās un predisponējošās alēles.

\section{Darba zinātniskā novitāte}

Darba gaitā tika pierādīta saistība starp konkrētiem bioķīmiskajiem, imūnǵenētiskajiem marķieriem un radiologiskajiem raksturlielumiem un slimības attīstību un komplicētību, kā arī tās saistība ar terapijas raksturlielumiem, tas l̦auj:

- izveidot ieteikumus praktizējošiem ārstiem, lai optimizētu pacientu izmeklēšanu un ārstēšanu;

- plānot farmakologískās terapijas ilgumu un daḷēji paredzēt tās efektivitāti.

Iepriekš minētais pilnveidotu veselības aprūpi ehinokokozes pacientiem un finansiālo resursu izmantošanu.

Savukārt uzvedības riska faktoru apzināšana un imūng̀enētiskajos izmeklējumos noteikto protektīvo un predisponējošo alẹ̄lu konstatēšana l̦autu veikt šo grupu pacientu apzināšanu un mērķētu izmeklēšanu, lai iespējami agrīni varētu diagnosticēt šo slimību.

\section{Darba ētiskie aspekti}

Pêtījuma veikšanai 2012.gada 29. novembrī tika saņemta Rīgas Stradiña universitātes Ētikas komitejas aț̣auja (skat. pielikumā). 


\section{MATERIĀLI UN METODES}

\subsection{Pētījumā iesaistītie pacienti}

Pētījumā tika analizētas 144 ehinokokozes pacientu RAKUS un PSKUS pieejamā medicīniskā dokumentācija par laika periodu no 1999. gada 1. janvāra līdz 2015. gada 1. februārim.

Kā iekḷaušanas kritēriji, balstoties uz pieejamajām rekomendācijām pasaulē, tika izmantoti šādi rādītāji:

1) seroloǵiski apstiprināta ehinokokozes diagnoze;

2) radiologiski (vismaz USG) apstiprināta ehinokokoze;

3) viens no parazitozes skartajiem orgāniem ir aknas.

Atlases gaitā 28 pacienti pētîjumā netika iekḷauti, jo diagnoze nevar tikt uzskatīta par verificētu, ja ir tikai pozitīvas seroloǵiskās analīzes, jo iespējamas krusteniskas reakcijas ar citiem lentveida parazītiem. Savukārt, citi pacienti tika izslēgti no pētījuma grupas, jo tikai vienkāršas cistas (radiologisiski nav ehinokokozei tipiskās pazīmes) atrade aknās nevar tikt uzskatīta par ehinokokozi, turklāt, ja to neapstiprina serologiskās analīzes.

Tādējādi pētījumā tika iekḷauti 116 pacienti, kuriem laika periodā no 1999. gada 1. janvāra līdz 2015. gada 1. februārim, pirmo reizi tika apstiprināta ehinokokozes diagnoze, ko promocijas darba pētījuma ietvaros var uzskatīt par generālkopu ( $\mathrm{N}$ = 116), jo minētās ārstniecības iestādēs ir apkopota informācija par visiem Latvijā ar ehinokokozi slimojošajiem pacientiem minētajā laika posmā.

No iekḷautajiem 116 pacientiem 87 ir sievietes un 29 vīrieši, kuru vidējais vecums bija 54,3 gadi ( $\mathrm{SD} \pm 16,2)$. Echinococcus granulosus infekcija tika verificēta 87 pacientiem, bet 29 Echinococcus multilocularis infekcija. 


\subsection{Anketēšana}

Papildus, lai noskaidrotu saslimšanas riska faktorus, tika veikta ehinokokozes un no ehinokokozes brīvu pacientu anketēšana par iespējamajiem saslimšanu ietekmējošajiem riska faktoriem. No 116 Latvijas ehinokokozes pacientiem, kuru dati tika izmantoti sākotnējai analīzei, 31 pacients uz anketēšanas veikšanas brīdi bija miris, tādējādi 85 ehinokokozes pacienti tika aicināti piedalīties aptaujā. 38 pacienti dažādu iemeslu dēḷ nevēlējās ierasties uz anketēšanu, tāpēc informācija par potenciālajiem riska faktoriem tika iegūta no 47 pacientiem. Pieņemot, ka ǵenerālkopā šai izlasei ir 85 pacienti, izlases kḷūda sanāca 9,8\%, rēḳinot ar 95\% ticamības līmeni. Iegūtais kḷūdas rezultāts pārsniedz ierasto $5 \%$ robežu, taču nepārsniedz 10\%, tādējādi izgūto izlasi varētu attiecināt uz visu generālpopulāciju.

Anketēšanā iesaistīto pacientu papildus atlase notika pēc šādiem kritērijiem:

1) pierādīts parazitozes gadījums - pozitīva serologiiskā atrade un raksturīga radioloǵiskā (galvenokārt, ultrasonogrāfiskā vai datortomogrāfiskā) aina;

2) diagnoze tika noteikta laika periodā no 1999. gada līdz 2015. gadam;

3) pacients vismaz 15 gadus bija dzīvojis Latvijā un bija dzīvs;

4) pacients deva individuālu piekrišanu piedalīties pêtījumā.

Kontroles grupas indivīdi, balstoties uz pētījuma plānojumu, tika izvēlēti līdzīgi pacientiem pēc sekojošiem kritērijiem:

1) vecums (ar iespējamu novirzi $+/-5$ gadi);

2) dzimums;

3) dzīvesvieta (dzīvojuši tajā pašā teritorijā, kur pacienti, vismaz 15 gadus); 
4) pēdējo 5 gadu laikā ir bijusi veikta vēdera dobuma ultrasonogrāfija un būtiska patologija netika konstatēta.

Kontroles grupas indivīdi tika atlasīti no gimenes ārstu un infektologu praksēm no dažādiem Latvijas novadiem, lai pētījuma dalībnieki pārstāvētu visus Latvijas statistiskos reǵionus. Visi kontroles grupas indivīdi parakstīja, ka brīvprātīgi piekrīt piedalīties pētījumā.

Pētījumā izmantotā anketa tika apstiprināta Rīgas Stradiṇa universitātes Ētikas komitejā.

Visi pētījuma dalībnieki tika anketēti ārsta klātbūtnē. Anketa sastāvēja no 45 jautājumiem šādas grupās: 1) pacienta dzīves apstākḷi (dzīvo dzīvoklī, mājā, lauku saimniecībā); 2) nodarbošanās, ja tā saistīta ar dzīvniekiem; 3) vai piederējuši suņi, kaķi (skaits, laika periods, turēšanas apstākḷi, dzīvnieku uzvedība, attārpošanas paradumi); 4) vai piederējuši mājlopi (veids, laika periods, turēšanas apstākḷi, kaušanas apstākḷi); 5) vai ir piederējis piemājas dārzs (veids, laika periods, kas tiek audzēts, mēslošana); 6) ogošanas un sēņošanas paradumi; 7) ceḷošanas anamnēze.

\subsection{Laboratorā diagnostika}

Darba gaitā izmantotie specifiskie un nespecifiskie laboratoriskie izmeklējumi tika veikti RAKUS Nacionālās mikrobiologijas references laboratorijā un RSU Imunologiijas un Imūnǵenētikas starpkatedru laboratorijā. Iegūto rezultātu novērtējums veikts atbilstoši testsistēmu ražotāju anotācijām.

\subsection{Ehinokokozes apstiprināšana}

Ehinokokozes apstiprināšanai tika izmantota specifisko antivielu noteikšana vai nu pret Echinococcus $s p$. ar ELISA metodi, vai pret Echinococcus granulosus, izmantojot aglutinācijas reakciju. Kā apstiprinošā 
metode tika izmantota Immunoblot metode, nosakot specifiskās IgG klases antivielas pret Ecinococcus spp. (iespēja identificēt Echinococcus granulosus un Echinococcus multilocularis).

Echinococcus sp. IgG: Antivielas pret Echinococcus sp. noteiktas, izmantojot ELISA metodi. Izmantotā testsistēma Novagnost Echinococcus IgG, Nova Tec Immundiagnostica GmbH, Vācija / Ridascreen Echinococcus IgG, R-biopharm, Vācija.

Echinococcus granulosus IgG: Antivielas pret Echinococcus granulosus noteiktas, izmantojot aglutinācijas reakciju (netiešā hemaglutinācija). Izmantotā testsistēma Echinococcus Serodiagnosis of hydatidosis by indirect haemagglutination; ELITech MICROBIO, Francija.

Echinococcus sp. IgG: Antivielas pret Echinococcus sp. noteiktas, izmantojot Immunoblot metodi. Izmantotā testsistēma ECHINOCOCCUS Western Blot IgG. Immunoblot asssay for in vitro diagnostic use. LDBIO ECHINOCOCCUS Western Blot IgG., LDBIO Diagnostics, Francija.

\subsection{Citokīnu noteikšana}

Citokīnu (IL-4, IL-10) koncentrācijas noteikšana veikta RSU Klīniskās Imunoloǵijas un Imūnǵenētikas starpkatedru laboratorijā.

Citokīnu līmeņa noteikšanai izmantots izmeklējamā pacienta asins serums. Venozās asinis iegūtas venopunkcijāa, izmantojot BD (Becton Dickenson) vakutainerus. Pacienta materiāls pēc iegūšanas centrifugēts, serums sadalīts eppendorf stobriņos un sasaldēts $-70^{\circ} \mathrm{C}$ līdz testa veikšanai.

IL-4, IL-10 līmenis noteikts pacienta izmeklējamajā materiālā, lietojot standarta ELISA (imūnfermentatīvo metodi), izmantojot Vector-Best testsistēmas, Krievija.

IFA-BEST (IL-4, IL-10) noteikšanai izmantota mikroplates cietās fāzes imūnfermentatīivā metode. Testā izmantotas monoklonālās antivielas pret 
dažādiem epitopiem. Kalibratori un izmeklējamais pacienta materiāls (100 mkl serums) reaǵē ar monoklonālajām antivielām (MKA1), ar ko nosegta mikroplate, un reaǵē ar monoklonālajām antivielām, kuras konjugētas ar peroksidāzi (100 mkl MKA2). Pēc inkubācijas veidojas komplekss MKA1 cilvēka (IL-4, IL-10) - MKA2-peroksidāze. Pēc inkubācijas mazgā mikroplati, lai atdalītu nesaistîtās antivielas. Pievieno hromogēnu (TMB), inkubē 25 minūtes un reakciju apstādina ar Stop-apstādināšanas šḳīdumu. Rezultātu nolasa ar fotometru (BiotecFluorescence Microplate Readers), izmantojot noteiktu viḷnu garumu $450 \mathrm{~nm}$. Fotokalorimetriski nolasītais optiskais blīvums ir tieši proporcionāls IL koncentrācijai izmeklējamajā materiālā. Pēc kalibratoru optiskajiem rādītājiem veido kalibrācijas līkni, no kuras nolasa izmeklējamā materiālā iegūtos (IL-4, IL-10) rezultātus. IL-4 - mērīšanas diapazons: 0-100 pg/ml; jutība: 0,4 pg/ml; IL-10 - mērǐšanas diapazons: 0-500 $\mathrm{pg} / \mathrm{ml}$; jutība: $0,1 \mathrm{pg} / \mathrm{ml}$.

\subsection{HLA genotipēšana}

HLA DRB1; DQA1; DQB1 gēnu tipēšana veikta RSU Klīniskās Imunoloğijas un Imūnǵenētikas starpkatedru laboratorijā.

DNS tiek izdalīta no leikocītiem, izmantojot komerciālo Qiagen komplektu DNS izdalīšanai no asinīm (QIAamp ${ }^{\circledR}$ DNA Blood Mini Kit), atbilstoši ražotāja apstiprinātai metodikai.

HLA-DRB1, -DQA1, -DQB1 gēnu tipēšana tika veikta ar zemas izšķiršanas polimerāzes k̦ēes reakciju (low resolution RT PCR-SSP Real-time PCR, qualitative analysis, melting curve analysis), lietojot sekvences specifiskos praimerus atbilstoši ražotāja noteiktajai metodikai (LLC DNA Technology, Russia). Identificēti galvenie HLA DR/DQ alēḷu tipi.

Pētījuma imūnǵenētisko marķieru (HLA) noteikšanas daḷā piedalījās tie paši 47 pacienti, kuri tika anketēti. HLA izmeklējumu rezultātu salīdzināšanai 
kā kontroles grupa tika izmantots materiāls no RSU Imunologijas un imūnǵenētikas starpkatedru laboratorijas datu bāzes, respektīvi, laboratorijā noteikti HLA veseliem asins donoriem.

Nosakot imūng̊enētiskos marķierus tika izmantoti jēdzieni "smaga" vai "komplicēta slimības" gaita, kas tika pielietots, ja:

1) pacientam bija ehinokokozes perēklis, kas lielāks par $10 \mathrm{~cm}$;

2) pacientam bija pieci vai vairāk parazitāro audu perēkḷi;

3) pacientam jau sākotnēji parazitāro audu izplatības dẹl nebija iespējama radikāla ķirurǵiska iejaukšanās;

4) pacientam pēc šķietami radikālas operācijas bija infekcijas recidīvs.

\subsection{Ultrasonoskopija}

N̦emot vērā, ka bija pieejami tikai ultrasonogrāfijas aprakstu dati, pētījuma laikā, balstoties uz šiem datiem, tika noteiktas arī cistiskās ehinokokozes stadijas. Stadijas tika noteiktas, balstoties uz PVO rekomendācijām. Stadija tika atzīmēta diagnozes noteikšanas brīdī un tad katru gadu.

1.1. tabula

Cistiskās ehinokokozes ultrasonoskopiskā klasifikācija

\begin{tabular}{|l|l|l|}
\hline Attēls & \multicolumn{1}{|c|}{ Attēlu raksturojums un piezīmes } & \multicolumn{1}{c|}{ Piez̄̄mes } \\
\hline CL & - Statuss: aktīiva cista. & Parasti tās ir neparazitāras \\
& - Unilokulārs cistisks veidojums ar uniformu & cistas, bet varētu būt agrīnas \\
& anehogēnu saturu, nav skaidri definēta & stadijas ehinokokozes cistas. \\
& cistas sieniņa. & Pēc US nav patognomu \\
& - Parasti apal̦a, bet var būt ovāla. & pazīmju. Parasti \\
& - Izmērs: CLs $(<5 \mathrm{~cm})$, CLm $(5-10 \mathrm{~cm})$, & nepieciešamas papildus \\
& $\mathrm{CLl}(>10 \mathrm{~cm})$ & diagnostikas metodes. \\
\hline
\end{tabular}


1.1. tabulas turpinājums

\begin{tabular}{|c|c|c|}
\hline Attēls & Attēlu raksturojums un piezīmes & Piezīmes \\
\hline CE1 & $\begin{array}{l}\text { - Statuss: aktīva cista. } \\
\text { - Unilokulāra vienkārša cista ar uniformu } \\
\text { anehogēnu saturu. Var būt "sniegpārslu } \\
\text { pazīme", kas veidojas kapsulai kustoties. } \\
\text { - Cistas siena parasti nav redzama. } \\
\text { - Parasti apaļa vai ovāla. } \\
\text { - Izmērs: CE1s (<5 cm), CE1m }(5-10 \mathrm{~cm}) \text {, } \\
\text { CE11 (> } 10 \mathrm{~cm}) \text {. }\end{array}$ & $\begin{array}{l}\text { Parasti cista ir fertila. } \\
\text { Patognomās pazīmes ir cistas } \\
\text { siena un "sniegpārslu } \\
\text { pazīme". }\end{array}$ \\
\hline CE2 & $\begin{array}{l}\text { - Statuss: aktīva cista. } \\
\text { - Multivezikulāra, multiseptēta cista, kura } \\
\text { var būt pilnīgi vai dal̄ēi pildīta ar } \\
\text { meitascistām. Cistu septas var radīt "riteṇa } \\
\text { spieksu" simptomu vai meitascistas var radīt } \\
\text { "rozetes" vai “bišu šūnu” struktūru. } \\
\text { - Cistas siena parasti ir redzama. } \\
\text { - Parasti apaļa vai ovāla. } \\
\text { - Izmērs: CE2s }(<5 \mathrm{~cm}), \text { CE2m }(5-10 \mathrm{~cm}) \text {, } \\
\text { CE21 (>10 cm) }\end{array}$ & $\begin{array}{l}\text { Parasti fertila cista. US } \\
\text { pazīmes ir patognomas. }\end{array}$ \\
\hline CE3 & $\begin{array}{l}\text { - Statuss: Pārejas. } \\
\text { - Anehogēns saturs ar no sieniņas atdalījušos } \\
\text { laminēto membrānu, kas peld centrā, ko } \\
\text { raksturo kā "ūdensrozes” pazīmi. } \\
\text { - Unilokulāra cista, kas var saturēt } \\
\text { meitascistas (anehogēnas) un ehogēnākus } \\
\text { rajonus (pārtrauktas membrānas, } \\
\text { degeneneratīvas meitascistas). Šīs cistas var } \\
\text { atgādināt "kompleksas masas”. } \\
\text { - Var būt nepareiza apaļa forma, jo spiediens } \\
\text { cistā ir samazināts. } \\
\text { - Izmērs: CE3s (<5 cm), CE3m (5-10 cm), } \\
\text { CE31 (>10 cm). }\end{array}$ & $\begin{array}{l}\text { Pārejas stadijas cista, kurā } \\
\text { sācies deǵeneratīvs process. } \\
\text { US pazīmes ir patognomas, } \\
\text { galvenokārt deǵeneratīvas } \\
\text { pazīmes, kur cistas sieniņa ir } \\
\text { atdalījusies un pārtraukta. }\end{array}$ \\
\hline CE4 & $\begin{array}{l}\text { - Statuss: Neaktīva cista. } \\
\text { - Heterogēns hipoehogēns vai nehomogēns } \\
\text { deǵeneratīvs saturs. Nav meitascistu. } \\
\text { - Var būt redzama "vilnas kamola" pazīme, } \\
\text { kas liecina par degeneneratīvām membrānām. } \\
\text { - Izmērs: CE4s (<5 cm), CE4m }(5-10 \mathrm{~cm}) \text {, } \\
\text { CE41 }(>10 \mathrm{~cm}) \text {. }\end{array}$ & $\begin{array}{l}\text { Lielākā daḷa cistu nav fertīlas. } \\
\text { US pazīmes parasti nav } \\
\text { patognomas, ir nepieciešami } \\
\text { papildus diagnostiskie testi. } \\
\text { Diferenciāldiagnostiski ir } \\
\text { nozīme cistas sienas esamībai, } \\
\text { laterālai konusveida ēnai, } \\
\text { nelieliem kalcinātiem vai } \\
\text { ehogēnai vai neehogēnai } \\
\text { spirālei, ko redz aknu } \\
\text { veidojumā. }\end{array}$ \\
\hline
\end{tabular}


1.1. tabulas nobeigums

\begin{tabular}{|c|c|c|}
\hline Attēls & Attēlu raksturojums un piezīmes & Piezīmes \\
\hline CE5 & $\begin{array}{l}\text { - Statuss: Neaktīva cista. } \\
\text { - To raksturo bieza kalcinēta sieniṇa arkas } \\
\text { formā, kas dod konusveida ēnu. } \\
\text { Kalcinācijas pakāpe variē no daḹejas līdz } \\
\text { pilnīgai. } \\
\text { - Izmērs: CE5s }(<5 \mathrm{~cm}), \text { CE5m }(5-10 \mathrm{~cm}) \text {, } \\
\text { CE51 }(>10 \mathrm{~cm})\end{array}$ & $\begin{array}{l}\text { Cistas lielākajā dal̦ā gadījumu } \\
\text { nav fertīlas. Diagnoze parasti } \\
\text { ir neskaidra. Pazīmes ir } \\
\text { patognomas. }\end{array}$ \\
\hline
\end{tabular}

\subsection{Datu statistiskā apstrāde}

Pacientu raksturošanai izmantotas aprakstošās statistikas metodes. Kvantitatīvajiem datiem tika izvērtēts vidējais aritmētiskais (Mean, M) ar izkliedes rādītāju standartnovirzi (Standard Deviation, SD), bet, ja dati neatbilda normālajam sadalījumam, - mediāna (Median, Me) un starpkvartilu amplitūda (Interquartile range, IQR).

Rezultāti tika izvērtēti ar 5\% $\alpha$-kḷūdu, tādējādi, ja rezultātos iegūtā p-vērtība bija mazāka par 0,05, tika noraidīta nulles hipotēze un testa rezultāts tika atzīts par statistiski nozīmīgu.

Pacientu grupu kvalitatīvo atšksirību izvērtēšanai (gan pētījuma grupām, gan kontroles grupām) tika izmantots P̄̄rsona hī kvadrāta $\left(\chi^{2}\right)$ tests (Pearson's chi-squared test $\left.\left(\chi^{2}\right)\right) .2 \times 2$ tabulām papildus tika izmantots Fišera eksaktais tests (Fisher's exact test), ja kādā no $2 \times 2$ tabulas šūnām sagaidāmā vērtība (expected count) bija mazāka par 5. Lai novērstu viltus pozitīvu rezultātu, izmantojām Bonferroni korekciju. Lai izvērtētu riska heterogenitāti, tika izmantotas Mantel-Haenszel vai Yates korekcijas metodes.

Saistības noteikšanai starp mainīgajiem tika pielietota korelācijas analīze, Spīrmena rangu korelācijas koeficients (Spearman's rank correlation coefficient, $\left.\mathrm{r}_{\mathrm{s}}\right)$.

Lai novērtētu, kādi faktori ietekmē pacientu dz̄ivildzi, tikai izmantota Koksa regresija (Cox proportional-hazards regression). 
Datu apstrāde tika veikta, izmantojot datorprogrammu IBM SPSS Statistics, Version 22.0. 


\section{REZULTĀTI}

\subsection{Epidemioloğiskie dati}

Dati tika analizēti laika periodā no 1999. gada līdz 2015. gada februārim. Izvērtējot no jauna diagnosticēto gadījumu sadalījumu pa gadiem, var konstatēt, ka kopumā jauno gadījumu skaits ir svārstīgs, tomēr ir vērojama tendence, ka pēc 2004. gada jaunu gadījumu skaitam ir tendence pieaugt (skatīt 2.1. att.).

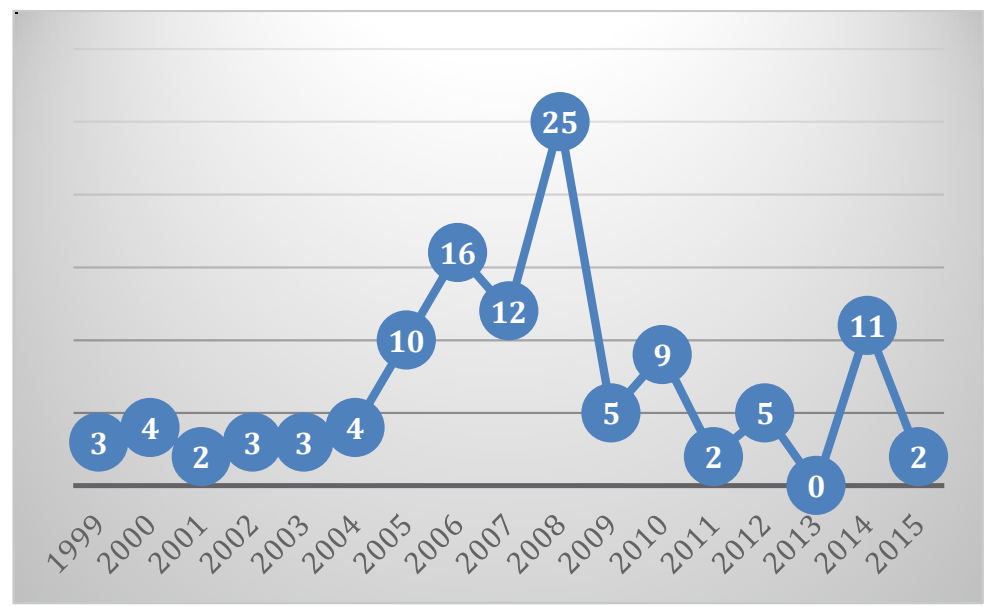

2.1. att. Apstiprināto ehinokokozes gadījumu skaits

Kopumā tika analizēta 116 pacientu liela grupa, no kuriem pārliecinoši vairāk - 87 (75\%) bija sievietes un tikai 29 (25\%) bija vīrieši (skatīt 2.2. att.). 


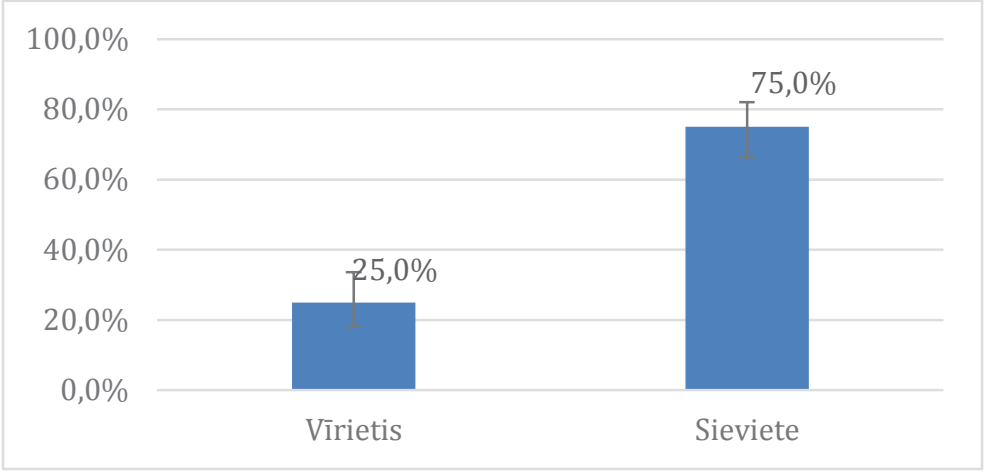

\section{2. att. Ehinokokozes pacientu sadalījums pēc dzimuma}

Darba gaitā tika arī analizēts, kur pacienti dzīvojuši vairāk kā 15 gadus, pēc 2.3. attēla redzams, ka liela daḷa pacientu dzīvojuši Kurzemē, atsevišķi Latgalē, tātad tuvāk Lietuvai, kur ir salīdzinoši liels šīs parazitozes gadījumu skaits katru gadu. Arī Rīgā ir samērā liels pacientu daudzums, tomēr jādomā, ka šajos gadījumos inficēšanās nav notikusi tur, bet gan reǵionos. Salīdzinoši maz pacientu ir no Vidzemes reǵiona, kas teritoriāli ir tuvāk Igaunijai, kur reg̣istrēto ehinokokozes gadījumu skaits ir ḷoti mazs.

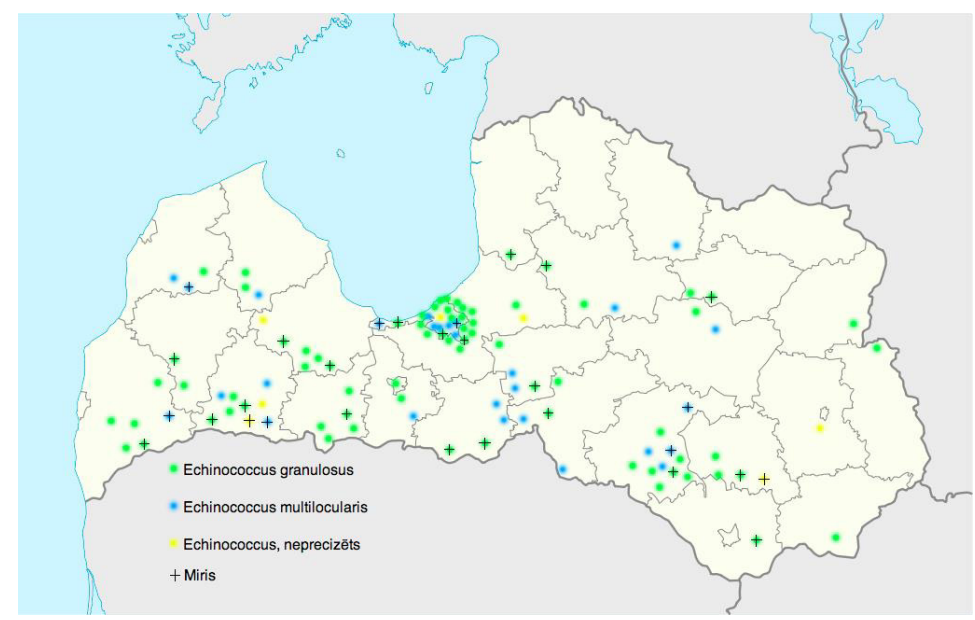

2.3. att. Ehinokokozes pacienti Latvijas teritorijā 
Diagnozes noteikšanas laikā vidējais vecums bija 54,3 gadi (SD $\pm 16,2)$, vecuma sadalījums atbilst normālsadalījumam (skatīt 2.4. att.).

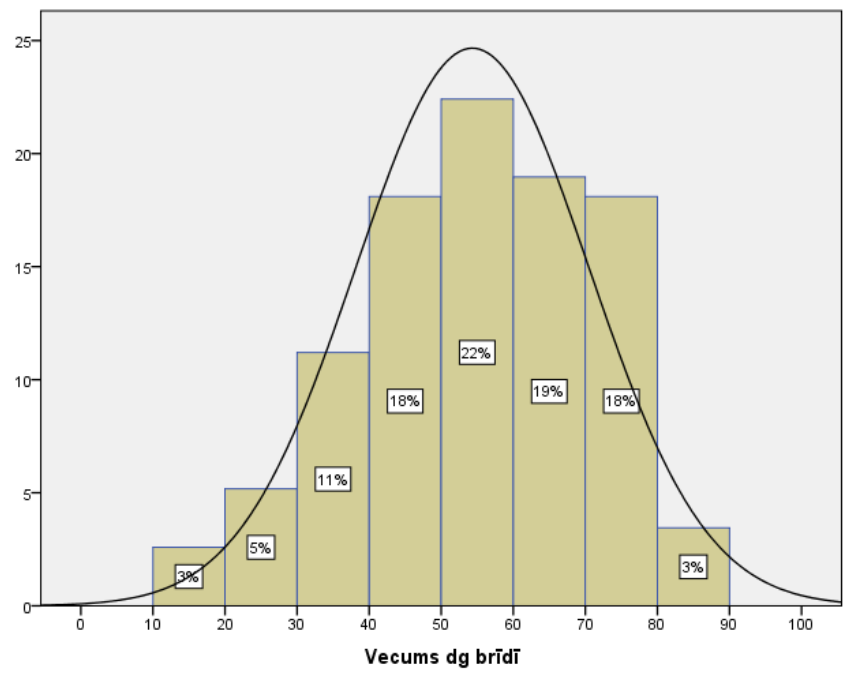

2.4. att. Ehinokokozes pacientu vecuma sadalījums

Salīdzinot pacientu vecumu diagnozes noteikšanas brīdī, vīriešu un sieviešu vecums statistiski nozīmīgi neatšķ̄īās $(\mathrm{p}=0,219)$.

Darba gaitā tika izvēlēts analizēt 12 biežākās sūdzības, kas aprakstîtas arī pieejamajā literatūrā. Sūdzības bija variablas, tomēr lielākajā dạ̦ā gadījumu bija saistītas ar gastrointestinālo sistēmu: visbiežāk 73 (62,9\%) pacienti minēja ādas niezi, 29 (25,0\%) diskomfortu vēderā un 24 (20,7\%) pastiprinātu nogurdināmību (skatīit 2.1. tabulu). 
Ehinokokozes pacientu sūdzības un to biežums $(\mathbf{N}=116)$

\begin{tabular}{|l|c|c|c|c|}
\hline \multicolumn{1}{|c|}{ Sūuzzību veids } & $\mathbf{n}_{\mathbf{1}}$ & İpatsvars, $\%$ & $\mathbf{9 5 \%}$ TI- & $\mathbf{9 5 \%}$ TI+ \\
\hline Nieze & 73 & 62,9 & $53,9 \%$ & $71,2 \%$ \\
\hline Slikta apetīte & 11 & 9,5 & $5,4 \%$ & $16,2 \%$ \\
\hline Caureja, nelaba dūša, vemšana & 2 & 1,7 & $0,5 \%$ & $6,1 \%$ \\
\hline Sāpes vēderā & 5 & 4,3 & $1,9 \%$ & $9,7 \%$ \\
\hline Diskomforts vēderā & 29 & 25,0 & $18,0 \%$ & $33,6 \%$ \\
\hline Nogurums & 24 & 20,7 & $14,3 \%$ & $28,9 \%$ \\
\hline Rūgtums mutē & 9 & 7,8 & $4,1 \%$ & $14,1 \%$ \\
\hline Dedzināšana & 3 & 2,6 & $0,9 \%$ & $7,3 \%$ \\
\hline Dzelte & 1 & 0,9 & $0,2 \%$ & $4,7 \%$ \\
\hline Svara zudums & 6 & 5,2 & $2,4 \%$ & $10,8 \%$ \\
\hline Sāpes mugurā & 1 & 0,9 & $0,2 \%$ & $4,7 \%$ \\
\hline Klepus & 3 & 2,6 & $0,9 \%$ & $7,3 \%$ \\
\hline
\end{tabular}

$\mathrm{n}_{1}$ - pacientu skaits ar minēto pazīmi

TI - ticamības intervāls

Analizējot sūdzību raksturu, kas varētu būt saistīts ar infekcijas esamību un pacientu vecumu, ir redzams, ka sāpes vēderā raksturīgākas vecākiem pacientiem $\left(\mathrm{r}_{\mathrm{s}}=0,189, \mathrm{p}=0,042\right)$, savukārt pastiprināta nogurdināmība raksturīga jaunākiem pacientiem $\left(\mathrm{r}_{\mathrm{s}}=-206, \mathrm{p}=0,026\right)$.

Analizējot sūdzību veidu un pacientu dzimumu, statistiski nozīmīgas atšksirības netika konstatētas.

\subsection{Diagnostikas īpatnības}

Pieeja diagnostikai ehinokokozes gadījumā tika balstīta uz diviem parametriem - seroloğiskajiem datiem un ultrasonoskopisko (USG) atradi. Parasti pirmais tika veikts radioloǵiskais izmeklējums, respektīvi USG, un tad diagnoze tika apstiprināta ar seroloǵisko metodi.

Analizējot sākotnējo USG aprakstu 113 pacientiem (trīs pacientiem aknās ehinokokozes perēkḷi netika konstatēti), sākotnējā slēdzienā ehinokokoze 
tika verificēta tikai $6(5,3 \%)$ gadījumos, visbiežāk - $46(40,7 \%)$ gadījumos slēdziens bija "aknu veidojums" (skatīt 2.2. tabulu).

2.2. tabula

Sākotnējā veidojumu ultrasonoskopiskā interpretācija

\begin{tabular}{|c|c|c|c|c|c|}
\hline $\begin{array}{l}\text { USG apraksta autora } \\
\text { piedāvātais slēdziens }\end{array}$ & $\mathbf{n}_{1}$ & $\mathbf{N}$ & $\begin{array}{c}\text { Īpatsvars, } \\
\% \\
\end{array}$ & $95 \%$ TI- & $95 \% \mathrm{TI}+$ \\
\hline Aknu veidojums & 46 & 113 & 40,7 & $32,1 \%$ & $49,9 \%$ \\
\hline Metastāzes & 1 & 113 & 0,9 & $0,2 \%$ & $4,8 \%$ \\
\hline Hemangioma & 16 & 113 & 14,2 & $8,9 \%$ & $21,8 \%$ \\
\hline Abscess & 2 & 113 & 1,8 & $0,5 \%$ & $6,2 \%$ \\
\hline Cista & 25 & 113 & 22,1 & $15,5 \%$ & $30,6 \%$ \\
\hline Ehinokoks & 6 & 113 & 5,3 & $2,5 \%$ & $11,1 \%$ \\
\hline Tumors & 18 & 113 & 15,9 & $10,3 \%$ & $23,8 \%$ \\
\hline Nav diferencētas aizdomas & 3 & 116 & 2,6 & $0,9 \%$ & $7,3 \%$ \\
\hline
\end{tabular}

USG - ultrasonogrāfija

$\mathrm{n}_{1}$ - pacientu skaits ar minēto pazīmi

$\mathrm{N}$ - kopējais pacientu skaits

Kopumā no 116 pacientiem, 80 pacientiem seroloǵiski tika noteikta Echinococcus granulosus infekcija un 29 pacientiem Echinococcus multilocularis infekcijas diagnoze, septinu pacientu gadījumos seroloǵiski nebija iespējams diferencēt parazīta apakštipu (skatît 2.3. tabulu).

2.3. tabula

Ehinokokozes seroloğiskā verifikācija $(\mathrm{N}=116)$

\begin{tabular}{|l|c|c|c|c|}
\hline \multicolumn{1}{|c|}{ Echinococcus veids } & $\mathbf{n}_{\mathbf{1}}$ & İpatsvars, \% & $\mathbf{9 5 \%}$ TI- & $\mathbf{9 5 \%}$ TI+ \\
\hline E. granulosus & 80 & 69,0 & $60,1 \%$ & $76,7 \%$ \\
\hline E. multilocularis & 29 & 25,0 & $18,0 \%$ & $33,6 \%$ \\
\hline Nav iespējams diferencēt & 7 & 6,0 & $3,0 \%$ & $11,9 \%$ \\
\hline
\end{tabular}

$\mathrm{n}_{1}$ - pacientu skaits ar minēto pazīmi

Analizējot iespējamo sakarību starp sākotnējām aizdomām par ehinokokozi (pēc USG) un seroloǵisko apstiprinājumu, secināts, ka gadījumos, kad serologiski nav iespējams diferencēt parazīta apakštipu, biežāk arī pēc 
sākotnējām aizdomām nediferencē veidojumu un biežāk ticis lietots termins "aknu veidojums" $\left(\mathrm{r}_{\mathrm{s}}=0,205, \mathrm{p}=0,029\right)$.

Izvērtējot iegūtos datus, kas atspoguḷoti USG, var secināt, ka aknas vairumam slimnieku sākotnēji (diagnozes noteikšanas laikā) ir normāla lieluma, ar tendenci laika gaitā mazināties, bet palielinās tādu pacientu skaits, kuriem tikusi veikta operācija; patologiiskajā procesā pārsvarā ir iesaistīta aknu labā daiva, bet ir tendence, slimībai progresējot, abu daivu iesaistei palielināties; progresējot slimības gaitai laikā, ir konstatêta tendence pieaugt perēkḷu skaitam (tomēr jāpiebilst, ka izvēlēts salīdzinoši īss laika periods, jo lielai daļai pacientu, pieaugot laikam, trūkst izmeklējumu); perēkḷa izmēri laika gaitā pārliecinoši nemainās; darba gaitā konstatēts, ka pieaugot novērošanas ilgumam, slimībai progresējot, palielinās tādu pacientu skaits, kuriem parazitārajā procesā ir iesaistīti žultsvadi un asinsvadi.

Tika arī meklēta sakarība, vai kādam no ehinokokozes veidiem ir kāda raksturīgāka USG atrade (pēc aknu izmēra, daivas iesaistes, perēkḷu skaita, izmēra), bet tāda netika iegūta.

Analizējot sakarību starp pacienta vecumu diagnozes noteikšanas brīdī un USG konstatētiem raksturlielumiem konstatēts - jo vecāks pacients, jo lielāks perēkḷu skaits $\left(\mathrm{r}_{\mathrm{s}}=0,215, \mathrm{p}=0,027\right)$.

Analizējot konstatēto sakarību starp sūdzību veidu un USG atradi, noskaidrots, ka perēklim atrodoties aknu kreisajā daivā, biežāk pacienti sūdzējušies par rūgtumu mutē $\left(\mathrm{r}_{\mathrm{s}}=0,365, \mathrm{p}<0,001\right)$.

\section{3. Ārstēšanas dati}

Lai novērtētu un analizētu pielietoto ārstēšanas taktiku apstiprinātas ehinokokozes gadījumā, tika analizēti pacientu individuālie saņemtās terapijas 
raksturlielumi. Turpmāk tekstā tiek lietots jēdziens etiotropās "terapijas kurss", kas nozīmē, ka terapija ir saņemta vismaz 30 dienas.

Tika konstatēts, ka etiotropā terapija gada laikā pēc diagnozes noteikšanas tika uzsākta lielākajai daļai - 82 (70,7\%) pacientu. Savukārt analizējot saņemtās terapijas atbilstību pieejamajām rekomendācijām noskaidrojās, ka pirmajā novērošanas gadā terapiju vismaz sešus mēnešus sañēma tikai 9 (7,8\%) pacienti. Konstatējot šo faktu, tika turpināts analizēt datus ar mērķi noskaidrot vai katram pacientam jebkad ir bijis 6 mēnešus ilgs terapijas kurss un izrādījās, ka tas bijis tikai 18 (15,5\%) pacientiem. Datu analīze arī parādīja, ka etiotropā terapija katru gadu ir bijusi tikai 58 (50,0\%) pacientiem.

Izvērtējot iepriekš minētos parametrus kontekstā ar parazīta veidu, tika konstatēts, ka pastāv korelācija starp parazīta veidu - Echinococcus multilocularis un terapijas shēmu - vismaz sešus mēnešus pirmajā terapijas $\operatorname{gadā}\left(r_{s}=0,205, p=0,028\right)$. Tomēr tālāk analizējot šos pacientus, statistiski nozīmīga korelācija ar to, ka terapija tiktu saņemta katru gadu, netika novērota $\left(r_{\mathrm{s}}=-0,085, \mathrm{p}=0,362\right)$. Ar Echinococcus granulosus un terapijas parametriem, statistiski nozīmīgas sakarības netika novērotas.

Analizējot individuāli viena pacienta saņemto terapijas kursu skaitu novērošanas perioda laikā, var secināt, ka kopējā terapijas kursu skaita vidējais aritmētiskais lielums bija 6,0 (SD $\pm 8,3$ ), ar mediānu 2. Minimāli tie bija nulle kursi, tātad netika saņemts neviens terapijas kurss, bet maksimāli tika saņemti 43 terapijas kursi.

Izvērtējot pieejamos datus, var secināt, ka kopumā pacienta saṇemtās terapijas ilguma mediāna ir viens gads $(\mathrm{p}<0,001)$, kas ir ievērojami mazāk nekā bija gaidīts.

Izvērtējot, vai var novērot korelāciju starp to, cik gadus pacients atrodas novērošanā un cik gadus saņem terapiju, var novērot statistiski nozīmīgu korelāciju $\left(\mathrm{r}_{\mathrm{s}}=0,604, \mathrm{p}<0,001\right)$, tātad ilgāk esot novērošanā arī terapijas 
ilgums pagarinās. Kā arī ir vērojama statistiski nozīmīga korelācija starp to, cik ilgi pacients atrodas novērošanā un kopējo terapijas kursu skaitu, tātad jo ilgāk pacientu novēroja, jo vairāk terapijas kursu pacients būs saņēmis $\left(r_{s}=0,51\right.$, $\mathrm{p}<0,001)$.

Svarīga ir iepriekš maz aprakstītā seroloǵisko rādītāju analīze, sasaistot etiotropās terapijas efektivitāti ar specifisku slimības rādītāju - specifiskajām antivielām pret Echinococcus kā tādu un tā veidu. Analīzes rezultāti l̦āva secināt, ka pozitīvs efekts tika novērots apmēram pusei - titrs mazinājās 31 (26,7\%) pacientam, bet tās piln̄īā izzuda 25 (21,6\%) pacientiem.

Izvērtējot antivielu titra izmaiņas var secināt, ka gadījumos, kad terapija uzsākta gada laikā pēc diagnozes verificēšanas, tad ir lielākas izredzes, ka antivielas izzudīs $(\mathrm{p}<0,001)$ (skatīit 2.5. att.).

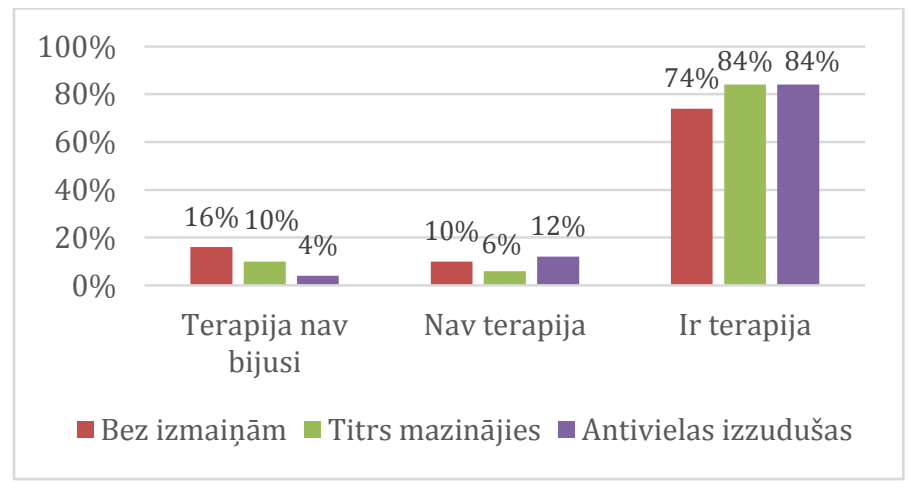

\section{5. att. Antivielu izmain̦as pacientiem, kuri terapiju saṇēmuši pirmā gada laikā}

Arī, ja terapija ir bijusi katru gadu, tad lielākas izredzes, ka antivielas izzudīs ( $<$ 0,001) (skatīt 2.6. att.). 


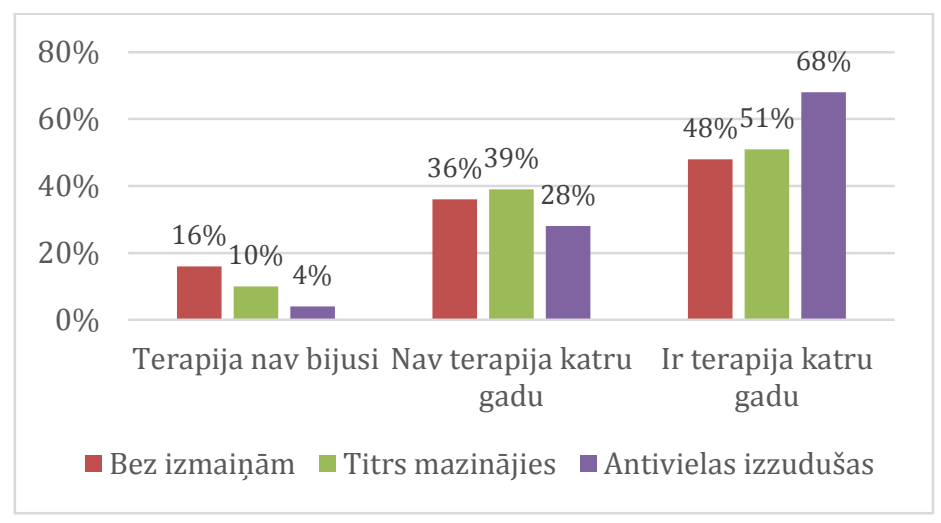

\section{6. att. Antivielu izmainas pacientiem, kuri terapiju saṇēmuši katru gadu}

Nozīmīgi, ka var vērot sakarību, ka pieaugot terapijas ilgumam, antivielu izzušanas iespēja palielinās $(p<0,001)$. Kā arī var vērot sakarību, ka pieaugot terapijas kursu skaitam, pieaug antivielu izzušanas varbūtība $(\mathrm{p}<0,001)$.

Analizējot sakarību starp ehinokokozes stadiju uz diagnozes noteikšanas brīdi un novērošanas perioda beigās, var secināt, ka stadijas vidēji pieaug par 0,2 punktiem. Salīdzinot ārstētos un neārstētos pacientus, var secināt, ka ārstētajiem pacientiem bija vērojams, ka stadija ir ar tendenci paaugstināties $(p=0,011)$, salīdzinot ar neārstētajiem, kur stadijas maiṇa nenotika.

2.4. tabula

Stadiju maiṇa ārstētiem un neārstētiem pacientiem

\begin{tabular}{|l|l|c|c|c|c|}
\hline \multicolumn{1}{|c|}{ Pacienti } & \multicolumn{1}{|c|}{ Novērošanas periods } & $\mathbf{M}$ & $\mathbf{Q}_{\mathbf{1}}$ & $\mathbf{M e}$ & $\mathbf{Q}_{\mathbf{3}}$ \\
\hline \multirow{2}{*}{$\begin{array}{l}\text { Neārstētie } \\
\text { pacienti }\end{array}$} & Stadija novērošanas sākumā & 3,3 & 2,8 & 3,5 & 4 \\
\cline { 2 - 6 } & Stadija novērošanas beigās & 3,3 & 2,8 & 3,5 & 4 \\
\hline $\begin{array}{l}\text { Ārstētie } \\
\text { pacienti }\end{array}$ & Stadija novērošanas sākumāa & $\mathbf{2 , 6}$ & 2 & 2 & 3 \\
\cline { 2 - 6 } & Stadija novērošanas beigās & $\mathbf{2 , 8}$ & 2 & 3 & 3 \\
\hline
\end{tabular}

$\mathrm{M}$ - vidējais aritmētiskais

Me - mediāna

$\mathrm{Q}_{1}$ - pirmā kvartīle

Q3 - trešā kvartīle 


\subsection{Imunoloğisko rādītāju analīze}

Darba gaitā tika izvērtēti arī imunoloǵiskie marķieri IL-4 un IL-10. IL-10 līmenis dažādiem pacientiem bija l̦oti svārstīgs $0-507,5$ pg/ml. IL-4 līmenis visiem pacientiem bija zem detekcijas līmeņa. Tika konstatēta statistiski nozīmīga korelācija ar IL-10 līmeņa paaugstināšanos un smagāku slimības gaitu alveolārās ehinokokozes gadījumā $\left(\mathrm{r}_{\mathrm{s}}=0,315, \mathrm{p}=0,031\right)$.

\subsection{Riska faktoru analīze}

\subsubsection{Epidemiologiskie riska faktori}

Salīdzinot ehinokokozes pacientu grupu un kontroles grupu, var secināt, ka atšķirību vecuma ziṇā nav ( $\mathrm{p}>0,05)$; jaunākais pacients bija 24 gadus vecs un vecākais pacients bija 84 gadus veca sieviete. Ehinokokozes pacientu grupā sieviešu bija statistiski nozīmīgi vairāk $(\mathrm{p}<0,05)$.

Analizējot anketas varēja secināt, ka

- $\quad$ pacientiem, kuriem bija bijuši suņi, kas netika turēti kontrolētos apstākḷos, risks iegūt ehinokokozi bija lielāks nekā tiem, kuri suņus turēja pie pavadas ārā vai suṇu novietnēs (OR 6,526, p <0,01).

- $\quad$ riska faktoram “suņu turēšanas aspekti” bija novērojama statistiski nozīmīga korelācija ar "redzēts, ka suns èd mazos grauzējus un/vai nokauto dzīvnieku iekšējos orgānus" $\left(\mathrm{r}_{\mathrm{s}}=0,754 ; \mathrm{p}<0,01\right)$.

- pacientiem, kuriem ir bijuši kaķi, risks iegūt ehinokokozi ir ievērojami augstāks nekā tiem, kuriem tie nav bijuši vai arī tie tiek turēti tikai iekštelpās (OR 3,325, p <0,05).

- $\quad$ riska faktoram "kaķu turēšanas aspekti” bija novērojama nozīmīga korelācija ar "redzēts, ka suns ēd mazos grauzējus un/vai nokauto dzīvnieku iekšējos orgānus" $\left(r_{s}=0,717 ; p<0,01\right)$. 
- $\quad$ ehinokokozes iegūšanas risks ir saistīts ar to, ka cilvēkam ir biežs kontakts ar suniem un kaķiem (OR 6,500; $\mathrm{p}<0,05)$.

- $\quad$ risks bija augstāks tiem, kas dzīvo lauku sētās (OR 57,646; $\mathrm{p}<0,01)$.

- $\quad$ risks bija augstāks tiem, kuriem kāds no ǵimenes ir mednieks (OR 4,498; $<<0,05)$.

Nozīmīgi riska faktori saistībā ar brīvā laika pavadīšanu, piemēram, dārzkopību, ogošanu, sēņošanu, netika novēroti.

\subsection{2. Ģenētiskie riska faktori}

Imūng̊enētiskās izmeklēšanas gaitā tika analizēta HLA II klases DRB1, DQA1 un DQB1 alēļu sastopamība gan visiem ehinokokozes pacientiem kopumā, gan arī atsevišķi cistiskās un alveolārās ehinokokozes grupās.

Kā kontroles grupa izmantots materiāls no RSU Klīniskās Imunologijas un Imūng̊enētikas starpkatedru laboratorijas datu bāzes: HLA izmeklējumi 100 veseliem asins donoriem vecuma grupā no 18 līdz 65 gadiem.

Cistiskās ehinokokozes pacientu grupā biežāk tika atrastas šādas alēles HLA-DRB1*17:01 (OR = 4,63; p < 0,000) un HLA-DRB1*07:01 $(\mathrm{OR}=5,65$; $\mathrm{p}<0,004)$. Savukārt, alēle -DRB1*15:01 (OR $=0,19 ; \mathrm{p}=0,001)$ bija reti sastopamas cistiskās ehinokokozes pacientu grupā un nozīmīgi retāk kontroles grupā. Jāpiebilst, ka atšķirības saistībā ar alēlēm HLA-DRB1*01:01, -DRB1*08:01 un -DRB1*13:01 sākotnēji šķita nozīmīgas, bet neizrādījās tādas pēc korekcijas ar Fišera metodi. Tātad, runājot par patoǵenēzi, cistiskās ehinokokozes gadījumā, iespējams, ka tikai HLA-DRB1*15:01 varētu būt protektīvs efekts.

Aleveolārās ehinokokozes pacientu grupā nozīmīgi biežāk tika konstatētas šādas alēles - HLA-DRB1*17:01 (OR = 3,07; p = 0,033), 
-DRB1*07:01 $(\mathrm{OR}=7,0 ; \mathrm{p}=0,014)$, bet ar alēli -DRB1* 11:01 atšķirības neizrādījās nozīmīgas pēc datu korekcijas ar Fišera metodi. Jādomā, ka tikai HLA-DRB1*17:01 un -DRB1*07:01 varētu būt nozīmīgs predisponējošs efekts. Savukārt, alēles -DRB1*13:01 (OR =0,39; $\mathrm{p}=0,591),-\mathrm{DRB} 1 * 15: 01$ $(\mathrm{OR}=0,23 ; \mathrm{p}=0,106)$ un $-\mathrm{DRB} 1 * 01: 01(\mathrm{OR}=0,78 ; \mathrm{p}=0,545)$ bija retāk vērojamas alveolārās ehinokokozes pacientu grupā, bet biežāk kontroles grupā, tomēr atšķirīibas neizrādījās nozīmīgi ticamas

Alēḷu asociācijas *04:01/*11:01 (OR =8,75, p =0,002), *17:01/*13:01 $(\mathrm{OR}=8,11, \mathrm{p}=0,037)$ un $* 11: 01 / * 13: 01(\mathrm{OR}=4,90, \mathrm{p}=0,044)$ bija saistītas ar smagāku slimības gaitu abās pacientu grupās. Atsevišķi cistiskās ehinokokozes grupā tās bija *04:01/*11:01 (OR =7,78, p =0,010), savukārt alveolārās ehinokokozes grupā $* 17: 01 / * 13: 01 \quad(\mathrm{OR}=16,33, \mathrm{p}=0,001)$, $* 04: 01 / * 11: 01(\mathrm{OR}=5,65, \mathrm{p}=0,04)$ un *11:01/*13:01 (OR = 7,84, $\mathrm{p}=0,022)$. Šajā grupā protektīvas alēles netika konstatētas.

Analizējot HLA-DQB1 alēļu grupu cistiskās ehinokokozes pacientiem, tika konstatēts, ka smagāka slimības gaita varētu būt saistāma ar HLADQB1*03:02 $(\mathrm{OR}=3,67 ; \mathrm{p}=0,02)$, HLA-DQB1*03:01 $(\mathrm{OR}=2,01$; $\mathrm{p}=0,033)$. Savukārt, alēles HLA-DQB1*05:01 (OR =0,25; $\mathrm{p}=0,047)$, -DQB1*06:02-8 (OR $=0,31 ; \mathrm{p}=0,013)$ bija reti sastopamas cistiskās ehinokokozes pacientu grupā, tātad tām varētu būt protektīvs efekts cistiskās ehinokokozes attīstībā.

Alveolārās ehinokokozes grupā varēja vērot saistību ar alēlēm HLADQB1*05:01 (OR = 3,18; p = 0,037), tātad jādomā, ka tām varētu būt nozīmīgs efekts attiecībā uz slimības patoǵenēzi, radot smagāku slimības gaitu. Svarīgi piebilst, ka HLA-DQB1*05:01 cistiskās ehinokokozes gadījumā bija protektīva alēle, bet alveolārās ehinokokozes gadījumā tai ir pretējs efekts. Savukārt, alēles -DQB1*03:02 (OR = 8,03; p = 0,643), -DQB1*04:01-2 (OR = 11,48; $\mathrm{p}<0,545)$ un -DQB1*06:02-8 (OR = 1,49; $\mathrm{p}=0$,091) bija retāk sastopamas pacientiem un biežāk kontroles grupā, bet atškirības neizrādījās statistiski 
nozīmīgas.

Analizējot visus ehinokokozes pacientus saistībā ar HLA-DQB1 alēlu grupām, tika secināts, ka kombinācijām *03:01/*03:02 (OR = 17,68, $\mathrm{p}=0,0004), * 02: 01-2 / * 03: 01(\mathrm{OR}=3,84, \mathrm{p}=0,047)$ un $* 03: 02 / * 06: 02-8$ $(\mathrm{OR}=4,02, \mathrm{p}=0,08)$ ir saistība ar smagāku klīnisko ainu.

Cistiskās ehinokokozes pacientu grupā kombinācijas *02:01-2/*03:01 $(\mathrm{OR}=5,17, \mathrm{p}=0,024), * 03: 01 / * 03: 02(\mathrm{OR}=33,00, \mathrm{p}=0,014)$ un *03:02/*06:02-8 (OR = 5,94, $\mathrm{p}=0,042)$ bija saistītas ar smagāku slimības gaitu un viena kombinācija *03:01/*03:02 (OR $=25,83, \mathrm{p}=0,0004)$ alveolārās ehinokokozes pacientu grupā. Un kā jau iepriekš minēts *03:01/*06:02-8 bija protektīvs efekts abās grupās - cistiskās ehinokokozes pacientiem $\mathrm{OR}=0,89$, $\mathrm{p}=0,05$ un alveolārās ehinokokozes pacientiem $\mathrm{OR}=0,87, \mathrm{p}=0,05$.

Tika analizēta arī HLA-DQA1 alēḷu grupa un tika secināts, ka cistiskās ehinokokozes pacientiem biežāk sastopama un varētu norādīt uz augstāku slimības smaguma risku bija *04:01 (OR $=3,84, \mathrm{p}=0,05)$, savukārt *01:02 $(\mathrm{OR}=0,28, \mathrm{p}=0,013)$ bija reti sastopama un iespējams ar protektīvu efektu. Alēles *01:03 (OR $=1,81, \mathrm{p}=0,181)$ un $* 02: 01(\mathrm{OR}=1,69, \mathrm{p}=0,204)$ bija retāk sastopamas nekā kontroles grupā, bet atškkirības neizrādījās statistiski nozīmīgas.

Alveolārās ehinokokozes pacientiem šajā alēḷu grupā *01:01 $(\mathrm{OR}=1,89, \mathrm{p}=0,291)$ un $* 03: 01(\mathrm{OR}=1,48, \mathrm{p}=0,388)$ bija nozīmīgi retāk sastopamas nekā kontroles grupā un tādēḷ tām varētu būt protektīvs efekts, bet tas neizrādījās satistiski nozīmīgi.

Alēḷu kombinācijas *01:03/05:01 (OR $=5,65, \mathrm{p}=0,040)$ un *03:01/05:01 (OR = 3,47, $\mathrm{p}=0,031)$ bija saistāma ar smagāku slimības norisi abās pacientu grupās, kā ar̄i alveolārās ehinokokozes grupā $(\mathrm{OR}=12,78$, $\mathrm{p}=0,001)$ un alēle $* 01: 01 / * 02: 01(\mathrm{OR}=10,78, \mathrm{p}=0,044)$ tikai alveolārās ehinokokozes grupā . 
2.5. tabulā redzami DRB1*/DQB1*/DQA1* nozīmīgie genotipi pacientiem ar cistisko un alveolāro ehinokokozi. 
$\frac{\pi}{3}$
$\frac{0}{\pi}$
ஸ்
ஸे

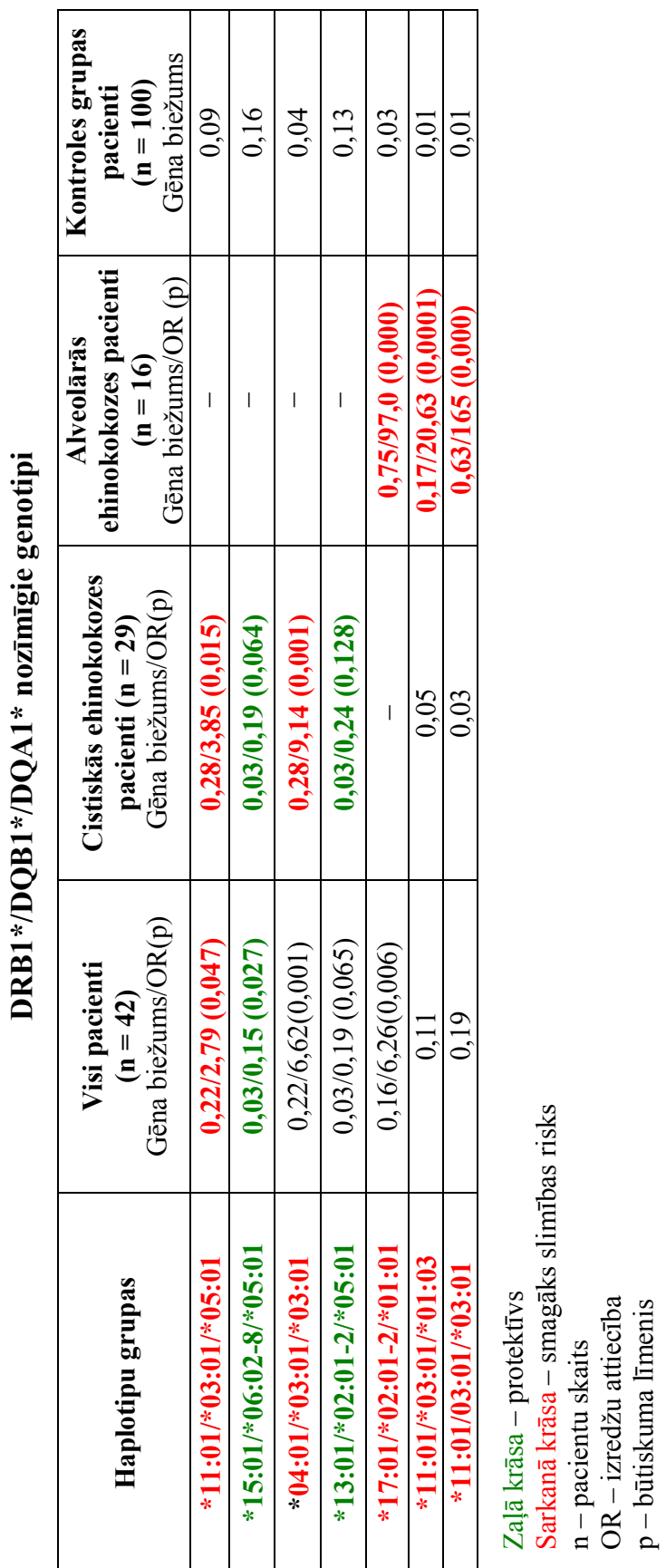




\subsection{Pētījumā iekḷauto pacientu mirstība}

Pētījuma laikā tika konstatēts, ka 31 no 116 pacientiem bija miris, no mirušajiem 13 pacientiem kā nāves iemesls tika norādīta ehinokokoze, 5 pacientiem nāves iemesls varēja būt saistīts ar ehinokokozi, jo tika norādīts ar aknu patologiju saistîts iemesls. Starp citiem nāves iemesliem bija malignitātes (prostatas vēzis, resnās vai taisnās zarnas vēzis, limfoma, plaušu vēzis, olnīcu vēzis), citas infekcijas slimības (pneimonija, spondilīts), čūlas slimība un ateroskleroze. 


\section{DISKUSIJA}

Pētījumā tika iesaistîti 116 pacienti, kuriem ehinokokozes diagnoze pirmo reizi tika noteikta laika periodā no 1999. gada līdz 2015. gada februārim. Analizējot no jauna reǵistrēto gadījumu skaitu, var vērot tendenci, ka sākot ar 2005. gadu no jauna pierādīto gadījumu skaitam ir tendence palielināties, sasniedzot visaugstāko līmeni 2008. gadā - kad gada laikā tika diagnosticēti 25 gadījumi, tad samazinoties un saglabājot līmeni 5-10 jaunie gadījumi katru gadu. Jādomā, ka gadījumu skaita pieaugums varētu būt saistīts ar jaunu serologisko diagnozes noteikšanas metožu parādīšanos un radiologisko izmeklējumu plašāku pieejamību, kā arī uzlabojoties medicīnas profesionāḷu zināšanām par šo parazitozi. Balstoties uz ECDC publicētajiem datiem par situāciju Eiropā, var secināt, ka ehinokokoze Latvijā var tikt uzskatīta par retu patologiju, salīdzinot ar pieejamajiem datiem par Eiropu. Salīdzinot ar citām Baltijas valstīm, Latviju var ierindot pa vidu, jo Lietuvā gadījumu skaits svārstās no 12-33 gadījumiem gadā, bet Igaunijā, lielākajā daḷā apskatīto gadu, jaunu gadījumu nav, izņemot 2007. gadu, kad bijuši divi gadījumi, 2013. gadu, kad bija trīs gadījumi un 2014. gadā viens gadījums (ECDC, 2006, 2007, 2008, 2008, 2009, 2010, 2011, 2013, 2014, 2015, 2016). Tomēr jāatceras, ka Latvijā ehinokokoze nav obligāti ziņojama infekcijas slimība, līdz ar to patiesais gadījumu skaits varētu būt arī lielāks.

Analizējot pacientu dzimumu, lielākā daļa pacientu - 75\% (87) bija sievietes un tikai $25 \%$ bija vīrieši, līdzīgi dati ir arī pētniekiem no Polijas (Nahorski et al., 2013), Ķīnas (Zhang et al., 2015, Yu et al., 2008), Čehijas (Kolarova et al., 2015), Azerbaidžānas (Vahedi et al., 2012) un Irānas (Hajipirloo et al., 2013). Bet analizējot divus pētījumus, kas veikti Peru, vienā ir uzsvērts, ka lielākā daļa pacientu ir vīrieši (Moro et al., 2004), bet otrā, ka atšķirības dzimumu starpā nav (Reyes et al., 2012). Arī pētījumā, kas veikts 
Spānijā, konstatēts, ka biežāk slimo vīrieši (Herrador et al., 2016). Pētījumā no Itālijas dažādiem reǵioniem konstatēts, ka dzimumu atšķirības nav (Tamarozzi et al., 2015), bet pētījumā, kas veikts tieši Sicīlijas regionā secināts, ka biežāk slimo vīrieši (Cappello et al., 2013). Savukārt pētîjumos, kas veikti Irānā (Sarkari et al., 2010) un Rumānijā (Moldovan et al., 2012) secināts, ka atšķirību starp dzimumiem nav. Šīs atšķirības dzimumu starpā varētu būt saistītas ar nodarbošanos, jo, ņemot vērā, ka inficēšanās bieži vien ir saistīta ar dzīves apstākḷiem, darbu ar mājlopiem un citiem mājdzīvniekiem, kas būs apskatīts tālāk. Dažādās valstīs ir dažādas tradīcijas - vai šos darbus vairāk dara sievietes vai vīrieši. Kā arī nozīmīgi varētu būt, vai šajā reǵionā ir izplatīta medniecība, ar ko biežāk nodarbojas vīrieši, kuriem ir lielāks kontakts ar dzīvniekiem, tai skaitā suņiem, un tas pamato šīs dzimumu atšķirīibas. Ekonomiski mazāk attīstītos reǵionos, piemēram, dažāâdos Ķīnā veiktos pētījumos, inficēšanās risks varētu būt saistīts ar kontaminētu ūdeni, tai skaitā, darbs ar kanalizācijas sistēmām.

Diagnozes noteikšanas brīdī pētījumā iekḷauto pacientu vecuma mediāna bija 54,3 gadi, lielākā pacientu daḷa bija vecuma grupā no 50 līdz 60 gadiem, kas varētu būt izskaidrojams ar slimības lēno gaitu, jo inficēšanos iespējams notiek agrīni, bet asimptomātiskais periods ir garš. Analizējot, vai kādam no dzimumiem diagnozes noteikšanas vecums atšķīrās, statistiski nozīmīga atšķirība netika konstatēta. Dati no citiem pētījumiem ir dažādi un pat pretrun̄̄gi. Piemēram, saskaņā ar ECDC datiem, laika posmā no 2005. gada līdz 2010. gadam lielākajā dạ̦ā ziņojumu minēts, ka vairums pacientu Eiropas reǵionā ir vecuma grupā no 45 līdz 64 gadiem (ECDC, 2005-2015), kas būtu līdzīgi mūsu datiem. Principā būtiskas atšksirības nav arī Polijā (Nahorski et al., 2013), kur vienā no pētījumiem minēts, ka pacientu vidējais vecums ir 47,7 gadi. Tomēr ir arī ziņojumi no valstīm, kas ir pretrunā ar mūsu rezultātiem, piemēram, pētījumā no Ķīnas minēts, ka pacientu vidējais vecums ir 45,6 gadi (Zhang et al., 2015), no Peru minēts, ka pacientu vidējais vecums ir 
47 gadi (Moro et al., 2004), Spānijā veiktā pētījumā konstatēts, ka lielākā daļa pacientu ir vecuma grupā virs 45 gadiem (Herrador et al., 2016), tomēr no citiem datiem vecuma grupā 65-74 gadi (Rojo-Vasquez et al., 2011). Pētījumā no dažādiem Itālijas reǵioniem konstatēts, ka pacientu vidējais vecums ir 59,8 gadi un 57\% pacientu ir vecāki par 60 gadiem (Tamarozzi et al., 2015), bet citā pētījumā, ka vidējais vecums ir 40 gadi (Brundu et al., 2014). Skatot precīzāk Sicîlijas reǵionu, konstatēts, ka vidējais pacientu vecums ir 46 gadi (Cappello et al., 2013). Pētîjumā no Irānas konstatēts, ka lielākais pacientu ippatsvars ir vecuma grupā 30-39 gadi (Sarkari et al., 2010) vai pat 20-39 gadi (Ahmadi et al., 2011; Gholami et al., 2018), bet no Pakistānas ir dati, ka lielākā daļa pacientu ir vecuma grupā 20-31 gads (Khan et al., 2018), jādomā, ka šajos reǵionos dzīves apstākḷi ietekmē to, ka pacienti ir salīdzinoši jauni. Arī pētījumā no Rumānijas uzsvērts, ka visaugstākā incidence ir vecuma grupā 45-65 gadi (Botezatu et al., 2018) vai 60-69 gadi (Moldovan et al., 2012).

Atsevišksās valstīs šì slimība pētīta bērnu vidū, piemēram, pētījumā no Bulgārijas (Jordanova et al., 2015) un Argentīnas (Dopchiz et al., 2009).

Ņemot vērā analizētos pētījumus var secināt, ka daudzos reǵionos, sevišķi Eiropā, pacientu vecumam nozīmīgu atškirību nav. Pacienti lielākoties ir vidēja vecuma, ko var skaidrot ar ehinokokozes ilgo inkubācijas un asimptomātisko periodu, kas nav licis pacientiem vērsties pie ārsta. Protams, reǵionos, kur slimība ir l̦oti izplatîta un ekspozīcija ar parazītu oliṇām ir ilgstoša un bieža, pacienti ir jaunāki, pat bērni, kā jau minēts, piemēram, Bulgārijā (Jordanova et al., 2015), kas Latvijā ir tikai atsevišķi gadījumi. Pretrunā tam tomēr ir citas valstis, jo, piemēram, Rumānijā, kas arī ir endēmisks reǵions, pacientu vecums ir virs 60 gadiem, tādēl jādomā, ka bez ekspozīcijas nozīmīgi ir citi faktori, piemēram, pacienta paša jeb ǵenētiskie faktori, kas arī tika pētīts šajā darbā un būs izklāstīts tālāk.

Analizējot Latvijas teritoriju kontekstā ar pacientu dzīvesvietu, var secināt, ka liela dạ̧a pacientu ir no Zemgales un no Latgales ziemel̦u dalas, 
savukārt Vidzemē praktiski nav šīs slimības gadījumu. Jādomā, ka tas ir saistīts ar slimības gadījumu skaitu kaimiņvalstīs, jo Lietuvā ir salīdzinoši daudz gadījumu, kas varētu izskaidrot lielāku mūsu pacientu skaitu Latgalē, savukārt Igaunijā gadījumu ir ļoti maz (Marcinkute et al., 2013), līdz ar to arī mūsu valsts ziemeļu dą̧ā gadījumu ir mazāk. Protams, šeit jāņem vērā arī iespējami inficēto dzīvnieku migrācija pāri valstu robežām.

Pētījumā tika analizētas arī pacientu sūdzības, kas viniiem lika vērsties pēc medicīniskās palīdzības. Analizējot sūdzības, tika secināts, ka 73 gadījumos pacienti bija minējuši, ka galvenā sūdzība bija ādas nieze, kas varētu būt izskaidrojama ar vairāk vai mazāk izteiktu holestāzi, kas veidojusies, jo ir žultscel̦u nospiedums, bet dzelte vēl nav klīniski konstatējama. Turklāt iespējams, ka šī sūdzība - ādas nieze, varētu būt saistīta ar alergisku reakciju pret parazītu. Tas skaidrots literatūrā tādējādi, ka parazīti ir spēcīgi IgE izdales izsaucēji (Bakiri et al., 2010), savukārt citi autori uzskata, ka alerǵizāciju var izsaukt arī minimāli cistu bojājumi, kad cistu saturs nonāk saskarē ar imūnās sistēmas šūnām (Siracusano et al., 2009). Mūsu dati nepārprotami apliecina pirmo skaidrojumu, jo tika secināts, ka daļai pacientu ir paaugstināts sārmainās fosfatāzes līmenis, kas ir viens no holestāzes marķieriem, tomēr nevar izslēgt arī otrās teorijas nozīmi, kas kopumā būtu jānnem vērā izvēloties ārstēšanas metodes. Saskaṇā ar mūsu pētījuma datiem, 29 gadījumos bija sūdzības par diskomfortu vēderā, kas ir plaši aprakstīts literatūrā (Nunnari et al., 2012; Branci et al., 2012, Fischer et al., 2016; Siracusano et al., 2012; Ymeonidis et al., 2013), bet 24 gadījumos pastiprināta nogurdināmība, kas medicīniskajā literatūrā minēts kā agrīni simptomi, kas varētu būt skaidrojams ar parazīta un saimniekorganisma mijiedarbību, turklāt minēts, ka biežāk to vēro alveolārās ehinokokozes gadījumā (Nunnari et al., 2012).

Tika minētas arī tādas sūdzības kā pasliktināta apetīte, rūgtums mutē, sāpes vēderā, dedzināšana, nelaba dūša, vemšana, šķidra vēdera izeja, kas minētas arī citu autoru publikācijās un varētu būt saistìtas ar hepatomegāliju un 
no tās izejošo orgānu saspiedumu vai kairinājumu (Nunnari et al., 2012; Branci et al., 2012, Fischer et al., 2016; Siracusano et al., 2012; Symeonidis et al., 2013). Parasti sūdzību intensitāte ir saistīta ar parazitāro audu plašumu, kas raksturīgs, jo palielinās parazitārais veidojums.

Pie iniciālajām, tātad tām, ar kurām pacients vērsās pēc palīdzības, sūdzībām tika minēta arī dzelte, bet tas ir saistāms ar vēlīnu ehinokokozes diagnostiku, kad jau ir attīstījušās nopietnas komplikācijas - maǵistrālo žultsceḷu nospiedums vai infiltrācija ar parazitārajiem audiem (Fischer et al., 2016; Siracusano et al., 2012; Ymeonidis et al., 2013; Stojkovic et al., 2015).

Tika arī secināts, ka sāpes vēderā bija raksturīgas vecākiem cilvēkiem, kas varētu būt saistîts ar lielāku parazitāro audu izplatību - plašāku aknu un tām blakusesošo audu iesaisti. Savukārt pastiprināta nogurdināmība bija raksturīga jaunākiem pacientiem, jāpiebilst, ka šāda sakarība pieejamajos literatūras avotos iepriekš nebija minēta.

Pacientu diagnoze tika balstîta uz diviem kritērijiem - radioloǵisko atradi, galvenokārt USG, un seroloǵisko atradi, kas bija atbilstoši rekomendācijām Eiropā (WHO, 2003).

Praktiski visiem (113 no 116) pacientiem tika konstatēts, ka jau sākotnēji parazitārais process ir skāris aknas. Tomēr, izvērtējot pirmā izmeklējuma datus, var secināt, ka diagnozes noteikšana ir sarežğīta, jo tikai sešiem pacientiem jau sākotnēji tika noteikta precīza diagnoze, tādēl svarīgi, ka diagnozes verifikācijai tiek izmantota arī otra metode. Visbiežāk USG tika aprakstîts aknu veidojums un netika precizēts, kas tas varētu būt, savukārt 25 gadījumos veidojums tika aprakstīts vienkārši kā cista, kas varētu atbilst agrīnām cistiskās ehinokokozes stadijām, kad vēl nav tai raksturīgo pazīmju (WHO, 2003). Radiologiskā atrade kā tumors tika raksturota 18 gadījumos, kas varētu būt diferenciāldiagnoze alveolārās ehinokokozes gadījumos, jo, kā jau minēts iepriekš, šai ehinokokozes formai raksturīga līdzīga gaita kā l̦aundabīgiem audzējiem (Liu et al., 2014; Kratzer et al., 2015). Veidojumu 
16 gadījumos aprakstīja kā hemangiomu, kas arī aprakstīts kā alveolārās ehinokokozes diferenciāldiagnoze (Liu et al., 2014; Kratzer et al., 2015). Retāk veidojums tika aprakstīts kā abscess vai metastāzes, arī metastāzes varētu būt diferenciāldiagnozes variants alveolārās ehinokokozes gadījumā (Kratzer et al., 2015). Savukārt trīs gadījumos sākotnēji USG netika konstatētas nekādas aknu izmaiņas, kas vēlāk izrādījās kḷūdaini, ko grūti skaidrot. Kā iespējamie iemesli varētu būt neliels veidojums, veidojums ļoti augstu aknu labajā daivā, kā arī nevar izslēgt aparatūras kvalitāti, kas arī ir nozīmīgs kritērijs.

Sākotnējā USG atrade tika analizēta sīkāk un tika konstatēts, ka visbiežāk aknas diagnozes noteikšanas brīdī ir parasta lieluma, bet ir tendence, ka pieaug tādu pacientu skaits, kuriem aknas ir operētas, ir iesaistīta aknu labā daiva, kas aprakstīts arī citu autoru publikācijās un kas skaidrojams ar aknu apasiņošanas īpatnībām (Nunnari et al., 2012; Zhang et al., 2015; Agudelo et al., 2016; Piarroux et al., 2011; Branci et al., 2011). Ir tendence, ka laika gaitā palielinās tādu pacientu skaits, kuriem ir iesaistītas abas aknu daivas, kas atkal var tikt skaidrots ar slimības progresiju. Progresējot slimībai, t.i. ejot laikam, ir vērojama tendence, ka samazinās tādu pacientu skaits, kuriem ir viens perēklis, kas iniciāli bija $61 \%$ pacientu, bet pieaug tādu pacientu skaits, kuriem ir divi vai multipli ( $\geq 5$ ) perēkḷi. Arī citos pētījumos ir aprakstīti līdzīgi dati (Nunnari et al., 2012; Zhang et al., 2015; Agudelo et al., 2016; Piarroux et al., 2011; Branci et al., 2012; Wuestenberg et al., 2014), piemēram, Turcijā tika konstatēts, ka solitāras cistas bija 60\% pacientu (Piarroux et al., 2011), $16,2 \%$ tika konstatētas multiplas cistas, arī no citiem literatūras datiem 20-40\% ir multiplas cistas (Nunnari et al., 2012). Sicīlijā veiktā pētījuma datiļauj secināt, ka pacientiem biežāk bija multiplas cistas $(60 \%$ gadījumu $)$ (Cappello et al., 2013).

Kā arī ir vērojama tendence, ka pieaug tādu pacientu skaits, kuriem ir iesaistîti aknu vai tām piegulošie asinsvadi, ir arī vērojama tendence, ka pieaug 
pacientu, kuriem iesaistīti (infiltrēti) žultsvadi, kas norāda uz slimības progresiju un iespējams arī uz pielietotās terapijas neefektivitāti.

Uz diagnozes noteikšanas brīdi perēkḷa lielums bija $6,9 \mathrm{~cm}(\mathrm{SD} \pm 4,2)$, mediāna $6,3 \mathrm{~cm}$. No Turcijā veiktā pētījuma datiem izriet, ka sākotnēji cistas bija 5,2 \pm 116,5 mm (Wuestenberg et al., 2014), no Ķīnas - 7,4 cm (Zhang et al., 2015), kas principā ir līdzịgi mūsu iegūtajiem rezultātiem. Tomēr netika novērota statistiski nozīmīga sakarība, ka perēkḷi laika gaitā palielinātos, ņemot vērā, kā tālāk būs aprakstīts, tika konstatēts, ka ārstēšana mūsuprāt ne vienmēr bija atbilstoša pieejamajām vadlīnijām.

Tā kā pacientu skaits nav liels un slimība progresē salīdzinoši lēnu, jautājums par visefektīvāko ārstēšanas taktiku ir diskusiju avots un arī autore ar darba grupu darba gaitā analizēja datus par to, kā pacienti tiek ārstēti un vai ir vērojamas sakarības starp ārstēšanas taktiku un slimības iznākumu.

No iegūtajiem rezultātiem var secināt, ka specifisko terapiju ar albendazolu gada laikā pēc diagnozes noteikšanas saņēma 70,7\% pacientu, tomēr iedziḷinoties terapijas shēmās bija redzams, ka dą̧ā gadījumu terapija netika saņemta pilnībā, jo sešu mēnešu nepārtraukta terapija pirmā gada laikā tika nozīmēta tikai 7,8\% gadījumu, bet jebkad ārstēšanas laikā sešu mēnešu kurss tika saṇemts $15,5 \%$ gadījumu. Jābilst, ka šādas terapijas shēmas nevar tikt uzskatītas par optimālām, jo terapijai būtu jābūt sākotnēji trīs līdz seši mēneši un gadījumos, ja parazitārais perēklis nevar tikt radikāli operēts, tai jābūt pastāvīgai (Hemphill et al., 2014; Tamarozzi et al., 2014; Vuitton, 2009). Savukārt no visiem pacientiem, kuriem netika veiktas ķirurǵiskas manipulācijas, katru gadu terapiju bija saņēmuši tikai puse pacientu. Tomēr jāpiemin arī, ka pacientiem, kuriem alveolārās ehinokokozes dēl ir bijusi ķirurǵiska iejaukšanās, medikamentoza terapija būtu bijusi jāsaņem vismaz divus gadus (Hemphill et al., 2014; Tamarozzi et al., 2014), tomēr darba gaitā analizētajiem pacientiem šī sakarība netika novērota, kas paaugstina risku slimības recidīviem. 
Darba gaitā tika iegūta nozīmīga korelācija starp parazịta veidu un terapijas ilgumu vienā no parametriem $(\mathrm{p}=0,028)$ - Echinococcus multilocularis gadījumos pacienti bija saņēmuši vismaz sešu mēnešu ilgu terapiju pirmā ārstēšanas gada laikā, tomēr tālāka sakarība ar kopējo terapijas ilgumu un kursu skaitu vairs netika vērota, kas ir negatīvi, jo inoperablos gadījumos terapijai būtu jābūt ilgstošai, iespējams, pat visu atlikušo mūžu.

Analizējot visu novērošanas laiku, var secināt, ka kursu skaita vidējais aritmētiskais lielums bija 6,0 (SD $\pm 8,3$ ) un kursu mediāna bija 2, kas ir ļoti maz un jāpiebilst, ka daḷa pacientu nekad nebija saṇēmuši nevienu terapijas kursu, bet lielākais rādītājs bija 43 kursi terapijas novērojuma perioda laikā un šie galējie dati kopumā norāda uz mūsu veselības aprūpes vājajām vietām. Arī literatūrā ir pieejami dati par līdzīga ilguma terapiju (Steinmetz et al., 2014), līdzīgi dati ar̄i pētījumā no pediatriskās populācijas (Moroni et al., 2016). Savukārt terapijas kopējā ilguma mediāna bija viens gads, kas ir izteikti mazs. Ir arī vērojama statistiski nozīmīga korelācija starp to, cik ilgi pacients ir novērots un cik gadus saņem terapiju ( $\mathrm{p}<0,001)$, un lielāku kopējo terapijas kursu skaitu $(\mathrm{p}<0,001)$.

Lai vērtētu, cik efektīva ir terapija, tika izmantotas divas metodes specifisko antivielu titra izmaiņas un cistu stadiju maiņa USG.

Vērtējot antivielu titra izmaiņas, pozitīvu efektu novēroja vairāk kā pusei pacientu - tās izzuda 21,6\% pacientu, bet titrs mazinājās $26,7 \%$ pacientu. Tika novērota arī statistiski nozīmīga korelācija starp terapijas uzsākšanu pirmā gada laikā un antivielu izzušanu, starp jebkad bijušu sešu mēnešu terapijas kursu un antivielu izzušanu. Pieaugot terapijas ilgumam un kursu skaitam, statistiski nozīmīgi $(\mathrm{p}<0,001)$ pieaug antivielu izzušanas varbūtība.

Vērtējot ehinokokozes stadijas maiṇu kontekstā ar terapiju, varēja vērot nozīmīgu sakarību starp saņemto terapijas kursu skaitu un stadijas mediānu - jo ilgāk tiek saṇemta terapija un pieaug terapijas kursu skaits, jo mazāks ir stadijas minimums, kas varētu norādīt uz to, ka ārstēšanai ir pozitīvs efekts, jo mazinās 
cistu, tātad parazitārā procesa, aktivitāte. Tomēr situācija nav unikāla, jo līdzīgi dati par nepieturēšanos starptautiskām vadlīnijām ir arī no citām valstīm (Nabarro et al., 2015).

Analizējot parazitozes sākotnējo stadiju un kāda tā bija novērošanas perioda beigās, var secināt, ka stadijas pieaugums ir 0,2, kas ir minimāls, bet tomēr var tikt uzskatīts par pozitīvu tendenci. Kā arī var secināt, ka ārstētajiem pacientiem bija vērojams, ka stadija ir ar tendenci paaugstināties, salīdzinot ar neārstētajiem, kur stadijas maiņa nenotika $(\mathrm{p}=0,011)$. Minēto var uzskatīt par pozitīvu tendenci, tomēr salīdzinot ar datiem no pieejamās literatūras, rezultātiem vajadzētu būt pārliecinošākiem, jo, piemēram, pieejamajās publikācijās ir minēts, ka pēc 1-2 terapijas gadiem 50-75\% 1. stadijas cistu un $30-55 \%$ 2. un 3. stadijas cistu bija kḷuvušas neaktīvas vai izzudušas (Nazligul et al., 2015; Stojkoviz et al., 2009).

Diemžēl citiem USG rādītājiem - aknu lielumam, aknu daivas iesaistei, perēkḷu skaitam un izmēriem - nevarēja novērot sakarību ar terapijas parametriem.

Atbilstoši norādēm literatūrā, kā iespējamie prognostiskie rādītāji darba gaitā tika izvērtēti arī imunoloǵiskie marķieri IL-4 un IL-10. Tika konstatēta statistiski nozīmīga korelācija starp IL-10 līmeņa paaugstināšanos un smagāku slimības gaitu alveolārās ehinokokozes gadījumā. Arī literatūrā ir pieejami dati par IL-10 - paaugstināts tā līmenis varētu būt raksturīgs aktīvai infekcijai un tam ir nozīme parazīta izdzīvošanā gan cistiskās (Pang et al., 2014; Mourglia-Ettlin et al., 2011; Shan et al., 2011), gan alveolārās ehinokokozes gadījumā (Tuxun et al., 2015). Pētījumā ar pelēm ir dati par to, ka inficētām pelēm IL-10 līmenis bija augstāks nekā veselām pelēm (Pan et al., 2017). Citos pētījumos, kas arī ir ar laboratorijas dzīvniekiem, secināts, ka paaugstināts interleikīna līmenis var liecināt par slimības aktivitāti un hronizāciju (Wang et al., 2014; Hu et al., 2015; Wang et al., 2015). Ir arī pieejami pêtījumi par to, ka IL-10 līmenis pacientiem, kas sliktāk atbild 
ķirurǵiskai vai farmakoloǵiskai terapijai, saglabājas augsts (Naik et al., 2016; Amri et al., 2009). Kā arī ir pieejami dati, kur tiek aprakstīts, ka paaugstināts IL-10 līmenis ir nozīmīgs, aţ̦aujot parazìtam izvairīties no imūnās sistēmas un persistēt saimniekorganismā (Amri et al., 2009). Līdz ar to var uzskatīt, ka būtu apsverama biežāka šî marķiera izmantošana klīniskajā praksē. IL-4 līmenis pētāmajā pacientu grupā bija zem detekcijas līmeņa, tomēr to varētu arī izskaidrot ar ehinokokozes īpatnībām, jo ir pieejami dati par to, ka šīs parazitārās saslimšanas gadījumos interleikīna līmenis varētu būt zemāks, piemēram $\geq 0,39 \mathrm{pg} / \mathrm{mL}$ (Petrone et al, 2015). Līdz ar to ehinokokozes gadījumos būtu nepieciešams izmantot vai nu testsistēmas, kurām ir zemāks detekcijas līmenis, vai arī būtu izmantojami citi imunologiskie rādītāji. Kā arī svarīgi piebilst, ka šiem imunoloǵiskajiem marķieriem varētu būt loma, uzlabojot ehinokokozes diagnostiku, tomēr tie nav specifiski šai parazitozei. Līdz ar to, lai tos varētu pilnvērtīgi izmantot, būtu jāizslēdz dažādi faktori, piemēram, pacientu blakussaslimšanas, vecums, kas diemžēl ne vienmēr ir iespējams.

No vienas puses dažādās teritorijās iegūtie dati par riska faktoriem ir līdzīgi pēc būtības, tomēr katrā valstī un teritorijā tiem ir atšķirību nianses.

Salīdzinot mūsu pētījumā iegūtos riska faktorus, var secināt, ka līdzīgi dati ir arī no citiem pētījumiem dažādās pasaules vietās.

Kā nozīmīgus var minēt faktorus, kas saistīti ar mājlopu turēšanu un kaušanas paradumiem. Piemēram, fakts, ka ir piederējuši mājlopi Latvijas populācijā izrādījās nozīmīgs riska faktors, līdzīgi minēts arī pētījumā no Turcijas (Akalin et al., 2014). Tomēr no mūsu rezultātiem, izvērtējot dzīvnieku sugu, neviena no dzīvnieku šķirnēm neuzrādīja nozīmīgu risku. Arī "mājlopu kaušana mājas apstākḷıs” ir nozīmīgs riska faktors, līdzīgi arī pētījumos, kas veikti Čîlē (Acosta-Jamett et al., 2014), Peru (Moro et al., 2008), Argentīnā (Larrieu et al., 2002), Mongolijā (Acosta-Jamett et al., 2014) un Ķīnā (Yuan et al., 2017),. Jādomā, ka tas ir saistîts ar iekšējo orgānu izbarošanu suņiem. 
Vienā no pētījumiem, kas veikts Ķ̄inā, kas ir ehinokokozes endēmiskais reǵions, kā nozīmīgs riska faktors tika minēts "nokauto mājlopu iekšējo orgānu izbarošana suņiem” (Wang et al., 2014), līdzīgi dati arī no Peru (Moro et al., 2008) un Argentīnas (Larrieu et al., 2002). No mūsu datiem arī šis neizrādījāa nozīmīgs faktors, tomēr šeit būtu jāņem vērā dažādie ikdienas sadzīves paradumi, kas ir izteikti atšşirīgi Latvijā un Ķīnā, un Dienvidamerikas valstīs. Iespējams, ka nozīme ir arī slimības zemajai prevalencei Latvijā, jo anketēšanas laikā, jautājot par to, vai ir redzēti izmainīti dzīvnieku iekšējie orgāni, neviens no pacientiem nebija atbildējuši apstiprinoši.

Daudzos pētījumos kā nozīmīgi tiek minēti dažādi ar mājdzīvniekiem, galvenokārt, suņiem un kaķiem un to turēšanu, saistīti faktori. Mūsu pētījumā fakts, ka ir piederējis suns, neizrādījās nozīmīgs riska faktors, kas ir līdzīgi uzsvērts arī pētījumos, kas veikti Irānā (Harandi et al., 2011) un Turcijā (Akalin et al., 2014), turpretim citos avotos, piemēram, Argentīnā (Bingham et al., 2014), tas ir nozīmīgs riska faktors. No mūsu datiem risku palielina dzīvnieku skaits un var secināt, jo vairāk dzīvnieku ir piederējis dzīves laikā, jo lielāks risks. To apstiprina dati par suņu skaitu pētījumā, kas veikts Peru (Alkalin et al., 2014), Pakistānā (Haleem et al., 2018), Argentīnā (Moro et al., 2008) un vairāk kā 5 suņi Ķīnā (Wang et al., 2014; Yang et al., 2006; Li et al., 2015). Nozīmīgi neizrādījās dzīvnieku turēšanas apstākḷi, tas, ka suns dzīvo nepieskatîts, kas ir norādīts kā riska faktors vairākos citos pētījumos, piemēram, no Peru (Moro et al., 2008). No mūsu datiem arī fakts, ka pieder brīvi dzīvojošs kaķis var tikt uzskatīts par riska faktoru, tomēr līdzīgus datus literatūrā neatradām.

Viens no pētījumā izvirzītajiem darba mērķiem un uzdevumiem bija noteikt ehinokokozes pacientu vidū sastopamās MHC HLA II klases gēnu alēles un to saistību ar slimības smagumu.

Analizējot HLA DRB1 gēnu alēḷu sastopamību, var secināt, ka pacientiem ar smagāku cistiskās ehinokokozes gaitu biežāk ir sastopamas alēles 
*17:01 un *07:01. Alēles *07:01 saistība ar paaugstinātu slimības risku ir aprakstīta pētījumā no Ķīnas, bet jāpiebilst, tas gan ir saistîbā ar alveolāro ehinokokozi (Mosayebi et al., 2013). Reti sastopamas, tātad varētu būt protektīvas, cistiskās ehinokokozes pacientu grupā ir alēles *01:01 un *15:01. Līdzīgi dati par alēles *01:01 protektīvo dabu ir minēti Krievijas (Lukmanova et al., 2011), Lebanonas (Chakhtoura et al., 2007), Saūda Arābijas (Hussein et al., 2012) un Turcijas (Aydinli et al., 2007) pētījumos. Pacientiem ar alveolāro ehinokokozi biežāk sastopamās alēles ir *17:01, *11:01 un *07:01. Par alēli *11:01 jāpiemin, ka pretrunīgi dati ir ar Vācijā veikto pêtījumu, kur šī alēle tiek uzskatīta par protektīvu alveolārās ehinokokozes gadījumā (Eiermann et al., 1998), līdzīgi dati arī no Turcijas (Aydinli et al., 2007), savukārt no dažādu Eiropas valstīs veikto pētījumu datiem var secināt, ka tai, iespējams, ir protektīvs raksturs cistiskās ehinokokozes gadījumā (Eiermann et al., 1998). Alveolārās ehinokokozes gadījumā kā protektīva tika izdalīta alēle *01:01. Jāpiebilst, ka dati, kas ir līdzīgi mūsu iegūtajiem, ir no tuvākiem reǵioniem, piemēram, Eiropas vai Krievijas, savukārt, daḷēji atšķirīgie dati ir no dažādām Āzijas valstīm un iespējams, ka šīs nesakritības ir izskaidrojamas ar ǵenētiskām rasu atšķirībām. Darba gaitā tika izanalizētas arī alẹ̄̂u asociācijas un tika secināts, ka visiem ehinokokozes pacientiem kombinācijas *04:01/*11:01, $*$ 17:01/*13:01 un *11:01/*13:01 bija saistītas ar smagāku slimības gaitu abās pacientu grupās. Atsevišķi cistiskās ehinokokozes grupā tā bija *04:01/*11:01, savukārt alveolārās ehinokokozes grupā *17:01/*13:01. Šajā grupā protektīvas alēlu kombinācijas netika konstatētas. Svarīgi piebilst, ka literatūrā dati par alēḷu kombinācijām nav pieejami.

Analizējot HLA-DQB1 alēlu sastopamību, var konstatēt, ka cistiskās ehinokokozes pacientu grupā nozīmīgi biežāk ir sastopamas alēles *03:02 un *03:01, savukārt alveolārās ehinokokozes grupā *05:01. Šeit mūsu datiem pretrunā ir literatūrā pieejamie dati no Irānas, kur šī alēle tieši tiek saistīta ar zemāku cistiskās ehinokokozes attīstības risku (Mosayebi et al., 2013), kas 
varētu būt izskaidrojams ar to, ka šajā populācijā jau varētu būt nozīmīgas ǵenētiskas atšksirības no Latvijas populācijas. Svarīgi piebilst, ka alēlēm *05:01 un *06:02-8 cistiskās ehinokokozes gadījumā bija protektīvs efekts, bet alveolārās ehinokokozes gadījumā pretēji - to biežāk sastop pacientiem ar smagu slimības gaitu. Analizējot visus ehinokokozes pacientus saistībā ar HLA-DQB1 alęlu grupām, tika secināts, ka kombinācijām *03:01/*03:02, *02:01-2/*03:01 un *03:02/*06:02- ir saistība ar smagāku klīnisko ainu, bet kombinācijai *03:01/*06:02-8 varētu būt protektīvs efekts. Analizējot alēlu kombinācijas attiecībā uz pacientu grupām - cistiskās ehinokokozes pacientu grupā kombinācijas *02:01-2/*03:01, *03:01/*03:02 un *03:02/*06:02-8 bija saistītās ar smagāku slimības gaitu un tā bija tikai viena kombinācija *03:01/*03:02 alveolārās ehinokokozes pacientu grupā.

Analizējot HLA-DQA1 alēḷu sastopamību, var konstatēt, ka cistiskās ehinokokozes pacientu grupā nozīmīgi biežāk ir sastopama alēle *04:01, bet reti sastopama ir alēle *01:02. Alveolārās ehinokokozes pacientu grupā statistiski nozīmīgas alēles atrast neizdevās. Piejamajos literatūras avotos datu par HLA-DQA1 alēļu saistību ar ehinokokozi nebija. Šeit iegūtie dati varētu tikt izmantoti līdzīgos pētijumos citās Baltijas un arī Eiropas valstīs, kas dotu daudz lielāku datu bāzi iespējamo līdzību un atšksirību konstatēšanai. Runājot par alẹḷu kombinācijām, tika secināts, ka *01:03/05:01 un *03:01/05:01 bija saistāma ar smagāku slimības norisi abās pacientu grupās un tikai *01:01/02:01 alveolārās ehinokokozes pacientu grupā.

Analizējot padziļināti, var secināt, ka cistiskās ehinokokozes grupā ar smagāku slimības gaitu, var izdalīt šādus haplotipus: HLA-DRB1*04:01/DQB1*03:01/-DQA1*03:01, HLA-DRB1*11:01/-DQB1*03:01/-DQA1*05:03. Savukārt alveolārās ehinokokozes grupā var izdalīt šādus genotipus: HLADRB1*17:01/DQB1*02:01-2/DQA1*01:01, HLA-DRB1*11:01/DQB1*03:01/ DQA1*03:01. 
Kā protektīvus visās pacientu grupās var izdalīt sekojošus haplotipus: DRB1*15:01/DQB1*06:02-8/DQA1*03:01 un HLA-DRB1*13:01/ DQB1*02:01 -2/DQA1*05:01.

Darba gaitā ir tikuši pētīti iespējamie uzvedības riska faktori un ǵenētiskie riska faktori, tomēr autore gribētu piebilst, ka ne tikai tiem ir nozīme. Slimības attīstībā nenoliedzami ir nozīme arī paša parazīta faktoriem, piemēram, genotipam, kas šajā darbā nav ticis pētīts, bet būtu apsverama šādu datu iegūšana citos perspektīvos pētījumos.

Imūnǵenētiskie dati varētu būt nozīmīgi, lai atbilstoši pacienta īpatnībām varētu plānot terapiju, jo šobrīd nav pieejami dati par to, kāds būtu optimālais terapijas ilgums un vai to ir iespējams pārtraukt, neveicinot infekcijas recidīvu. Zināms, ka ir pacienti, kuriem slimība progresē lēni un nerada nopietnas komplikācijas, bet jāpatur prātā, ka ir pacientu grupa, kurai pat neilga terapijas pārtraukšana izraisa strauju parazitārā procesa aktivitātes pieaugumu.

Pētījuma laikā tika konstatēts, ka 31 no 116 pacientiem bija miris, mirušajiem 13 pacientiem kā nāves iemesls tika norādīta ehinokokoze, pieciem pacientiem nāves iemesls varēja būt saistīts ar ehinokokozi, jo kā iemesls tika norādīts ar aknu patoloǵiju saistīts iemesls. Tomēr jāṇem vērā, ka šis skaitlis varētu izrādīties lielāks, jo iespējams, ka nav tikusi izvērtēta ehinokokozes ietekme uz organismu kopumā un varētu būt, ka, piemēram, gadījumos, kad kā nāves iemesls ir uzrādīta infekcija, ehinokokoze ir bijusi nozīmīgs nāves veicinātājs, ņemot vērā jau iepriekš aprakstītās izmaiņas aknu parametros, kas varēja radīt olbaltumvielu, tai skaitā antivielu, sintēzes traucējumus, vai arī jau minētās interleikīnu izmaiņas, kas var būt saasinājušas infekciju norisi.

Pētījuma rezultātā var konstatēt, ka pacienta stāvoklim, ko raksturo gan bioķīmiski, gan imūnǵenētiski lielumi, ir liela nozīme terapijas efektivitātē, un tos ņemot vērā, jādomā, ka ir iespējams paaugstināt terapijas efektivitāti. 
Rezultāti arī apstiprina to, ka imūnǵenētiski faktori var dot būtisku ieskatu par slimības gaitu, tai skaitā, parazitārā procesa aktivitāti.

Veiktais pētījums dod nozīmīgu informāciju - genētiskās predispozīcijas un imūnās sistēmas iespējamo aizsardzību pret ehinokokozes attīstību. Ir nepieciešams turpināt slimības gaitas molekulāro mehānismu pētījumus, lai nākotnē būtu iespējams prognozēt un paredzēt tās iznākumus, kas nozīmētu, ka tiek piedāvāti jauni līdzekḷi un pieejas ārstēšanā, kā arī sagatavotas terapijas iespējas. 


\section{SECINĀJUMI}

1. Latvijā kā statistiski nozīmīgi riska faktori ehinokokozes iegūšanai izrādījās:

1) dzīvošana lauku sētā, īpaši ilgstoša;

2) fakts, ka piederējuši mājlopi;

3) fakts, ka mājinieki nodarbojas ar medniecību;

4) ir piederējuši suņi un kaķi;

5) suņi un kaķi dz̄ivo nepieskatīiti un ir ēduši mazos grauzējus vai nokauto mājlopu iekšējos orgānus.

2. Lielākas izredzes, ka antivielas ārstēšanas rezultātā būs izzudušas, ja:

1) terapija ir bijusi jau pirmā gada laikā pēc diagnozes noteikšanas;

2) jebkad ir bijis sešu mēnešu terapijas kurss;

3) terapija ir bijusi katru gadu;

4) pieaugot terapijas ilgumam un kursu skaitam, palielinās antivielu izzušanas varbūtība.

3. Terapiju saņēmušajiem pacientiem tiek novērota sakarība, ka cistiskās ehinokokozes stadija ir ar tendenci palielināties.

4. IL-10 līmeņa paaugstināšanās var tikt izmantota kā pazīme, kas var liecināt par smagāku un komplicētu slimības gaitu alveolārās ehinokokozes gadījumā.

5. Lielāku risku nomirt statistiski nozīmīgi pastiprina paaugstināts EGĀ, SF, GGT un bilirubīna līmenis.

6. Cistiskās ehinokokozes gadījumā par slimības smagāku gaitu var liecināt HLA-DRB1 alēles *17:01 un *07:01, DQB1*03:01 un 03:02, DQA1*04:01 un haplotipi HLA-DRB1*04:01/DQB1*03:01/DQA1*03:01, HLADRB1*11:01/ DQB1*03:01/DQA1*05:01. 
7. Alveolārās ehinokokozes gadījumā par slimības smagāku gaitu var liecināt HLA DRB alēles *17:01 un *07:01, DQB1 *05:01 un haplotipi HLA-DRB1*17:01/DQB1*02:01-2/DQA1*01:01, HLA-DRB1*11:01/ QB1*03:01/QA1*01:03 un HLA-DRB1*11:01/DQB1*03:01/DQA1*03:01.

8. Cistiskās ehinokokozes gadījumā par protektīvām var uzskatīt HLA DRB1 alēles *15:01, DQB1*05:01 un *06:02-8, DQA1*01:02, alveolārās ehinokokozes gadījumā par protektīvām var uzskatît HLA DRB alēles *01:01, *15:01 un *13:01, HLA DQB1*06:02-8, HLA DQA1*01:02 un *05:01.

9. Kā protektīvus visās pacientu grupās var izdalīt šādus haplotipus: DRB1*15:01/DQB1*06:02-8/DQA1*03:01 un HLA-DRB1*13:01/DQB1 *02:01-2/DQA1*05:01. 


\section{PRAKTISKĀS REKOMENDĀCIJAS}

1. Rekomendācijas par diagnostiku:

1) diagnosticējot ehinokokozi, balstoties uz darba rezultātiem un gadījumu definīciju, tiek rekomendēts izmantot gan radioloǵisko, gan seroloǵisko atradi. Pārliecinoša radioloǵiskā atrade diagnostikai ir vērtējama augstāk nekā negatīva serologiskā atrade.

2) diagnosticējot ehinokokozi, izmantot visas sekojošās metodes: ELISA, IF, IB serologíiskās diagnostikas metodes, ņemot vērā, ka pirmās divas varētu būt jutīgākas, bet trešā ir specifiskāka. Kā arī jāṇem vērā, ka viena negatīva metode neizslēdz diagnozi un būtu vēlams izmantot visas.

2. Rekomendācijas par ārstēšanu:

1) medikamentozā ārstēšana:

a) būtu jāuzsāk pēc iespējas ātrāk pēc diagnozes noteikšanas;

b) tai būtu jābūt vismaz sešus mēnešus ilgai, ar sekojošu USG datu izvērtēšanu;

c) tai būtu jābūt pietiekoši ilgai, ja radikāla parazīta rezekcija nav iespējama, tad pretparazitārie medikamenti jālieto visu mūšu.

2) ārstēšanas ilguma plānošanā neskaidros gadījumos izmantojama genētisko alēḷu identificēšana, jo ir pierādīts, ka atsevišķas alēles ir saistāmas ar komplicētāku slimības gaitu;

3) ārstēšanas rezultāts jāvērtē kompleksi, izmantojot gan radiologiskos datus, gan serologiskos, gan imunoloǵiskos un imūnǵenētiskos datus un nedrīkst paļauties tikai uz vienu no rādītājiem. 


\section{LITERATŪRAS SARAKSTS}

1. The European Union summary report on trends and sources of zoonoses, zoonotic agents and food-borne outbreaks in 2007. 2009. EFSA J, 223.

2. The European Union summary report on trends and sources of zoonoses, zoonotic agents and food-borne outbreaks in 2009. 2011. EFSA J 9(3): 2090.

3. The European Union summary report on trends and sources of zoonoses, zoonotic agents and food-borne outbreaks in 2010. 2012. EFSA J 10(3): 2597. doi:10.2903/j.efsa.2012.2597.

4. The Community summary report on trends and sources of zoonoses, zoonotic agents and food-borne outbreaks in the European Union in 2008. 2010. EFSA Journal; 8(1): 1496.

5. The Community summary report on trends and sources of zoonoses, zoonotic agents, antimicrobial resistance and foodborne outbreaks in the European Union in 2005. 2006. The EFSA Journal, 94.

6. The Community summary report on trends and sources of zoonoses, zoonotic agents, antimicrobial resistance and foodborne outbreaks in the European Union in 2006. 2007. The EFSA Journal, 130.

7. The European Union summary report on trends and sources of zoonoses, zoonotic agents and food-borne outbreaks in 2007. 2009. EFSA J, 223.

8. The European Union summary report on trends and sources of zoonoses, zoonotic agents and food-borne outbreaks in 2009. 2011. EFSA J 9(3): 2090.

9. The European Union summary report on trends and sources of zoonoses, zoonotic agents and food-borne outbreaks in 2010. 2012. EFSA J 10(3): 2597. doi:10.2903/j.efsa.2012.2597.

10. The Community summary report on trends and sources of zoonoses, zoonotic agents and food-borne outbreaks in the European Union in 2008. 2010. EFSA Journal; 8(1): 1496.

11. The Community summary report on trends and sources of zoonoses, zoonotic agents, antimicrobial resistance and foodborne outbreaks in the European Union in 2005. 2006. The EFSA Journal, 94.

12. The Community summary report on trends and sources of zoonoses, zoonotic agents, antimicrobial resistance and foodborne outbreaks in the European Union in 2006. 2007. The EFSA Journal, 130.

13. Nahorski, W. L., Knap, J. P., Pawłowski, Z. S., Krawczyk, M., Polański, J., Stefaniak, J., Patkowski, W., Szostakowska, B., Pietkiewicz, H., Grzeszczuk, A., Felczak-Korzybska, I., Gołąb, E., Wnukowska, N., Paul, M., Kacprzak, E., Sokolewicz-Bobrowska, E., Niścigorska-Olsen, J., Czyrznikowska, A., Chomicz, L., Cielecka, D., Myjak, P. 2013. Human alveolar echinococcosis in Poland: 1990- 
2011. PLoS Negl Trop Dis. 7(1): e1986. doi: 10.1371/journal.pntd.0001986. Epub 2013 Jan 3. PubMed PMID: 23301116; PubMed Central PMCID: PMC3536814.

14. Zhang, T., Zhao, W., Yang, D., Piao, D., Huang, S., Mi, Y., Zhao, X., Cao, J., Shen, Y., Zhang, W., Liu, A. 2015. Human cystic echinococcosis in Heilongjiang Province, China: a retrospective study. BMC Gastroenterol. Mar 10; 15:29. doi: 10.1186/s12876-015-0256-8. PubMed PMID: 25887470; PubMed Central PMCID: PMC4358864.

15. Kolářová, L., Matějů, J., Hrdý, J., Kolářová, H., Hozáková, L., Žampachová, V., Auer, H., Stejskal, F. 2015. Human alveolar echinococcosis, Czech Republic, 2007-2014. Emerg Infect Dis. Dec; 21(12): 2263-2265. doi: 10.3201/eid2112.150743. PubMed PMID: 26583699; PubMed Central PMCID: PMC4672410.

16. Vahedi, M. A., Vahedi, M. L. 2012. Demographics of patients with surgical and nonsurgical cystic echinococcosis in East Azerbaijan from 2001 to 2012. Pak J Biol Sci. Feb 15; 15(4): 186-191. PubMed PMID: 22816176.

17. Hajipirloo, H. M., Bozorgomid, A., Alinia, T., Tappeh, Kh. H., Mahmodlou, R. 2013. Human cystic echinococcosis in west azerbaijan, northwest iran: a retrospective hospital based survey from 2000 to 2009. Iran J Parasitol. Apr; 8(2): 323-326. PubMed PMID: 23914247; PubMed Central PMCID: PMC3724159.

18. Moro, P. L., Lopera, L., Cabrera, M., Cabrera, G., Silva, B., Gilman, R. H., Moro, M. H. 2004. Short report: endemic focus of cystic echinococcosis in a coastal city of Peru. Am J Trop Med Hyg. Sep; 71(3): 327-329. PubMed PMID: 15381815.

19. Reyes, M. M., Taramona, C. P., Saire-Mendoza, M., Gavidia, C. M., Barron, E., Boufana, B., Craig, P. S., Tello, L., Garcia, H. H., Santivañez, S. J. 2012. Human and canine echinococcosis infection in informal, unlicensed abattoirs in Lima, Peru. PLoS Negl Trop Dis. 6(4): e1462. doi: 10.1371/journal.pntd.0001462. Epub 2012 Apr 3. PubMed PMID: 22509413; PubMed Central PMCID: PMC3317905.

20. Herrador, Z., Siles-Lucas, M., Aparicio, P., Lopez-Velez, R., Gherasim, A., Garate, T., Benito, A. 2016. Cystic echinococcosis epidemiology in Spain based on hospitalization records, 1997-2012. PLoS Negl Trop Dis. Aug 22; 10(8): e0004942. doi: 10.1371/journal.pntd.0004942. eCollection 2016 Aug. PubMed PMID: 27547975; PubMed Central PMCID: PMC4993502.

21. Tamarozzi, F., Rossi, P., Galati, F., Mariconti, M., Nicoletti, G. J., Rinaldi, F., Casulli, A., Pozio, E., Brunetti, E. 2015. The Italian registry of cystic echinococcosis (RIEC): the first prospective registry with a European future. Euro Surveill. May 7; 20(18). pii: 21115. PubMed PMID: 25990235.

22. Cappello, E., Cacopardo, B., Caltabiano, E., Li Volsi, S., Chiara, R., Sapienza, M., Nigro, L. 2013. Epidemiology and clinical features of cystic hydatidosis in Western Sicily: a ten-year review. World J Gastroenterol. Dec 28; 19(48): 93519358. doi: 10.3748/wjg.v19.148.9351. PubMed PMID: 24409062; PubMed Central PMCID: PMC3882408.

23. Sarkari, B., Sadjjadi, S. M., Beheshtian, M. M., Aghaee, M., Sedaghat, F. 2010. 
Human cystic echinococcosis in Yasuj District in Southwest of Iran: an epidemiological study of seroprevalence and surgical cases over a ten-year period. Zoonoses Public Health. Mar; 57(2): 146-150. doi: 10.1111/j.18632378.2008.01200.x. Epub 2009 Jan 19. PubMed PMID: 19175567.

24. Moldovan, R., Neghina, A. M., Calma, C. L., Marincu, I., Neghina, R. 2012. Human cystic echinococcosis in two south-western and central-western Romanian counties: a 7-year epidemiological and clinical overview. Acta Trop. Jan; 121(1): 26-29. doi: 10.1016/j.actatropica.2011.10.003. Epub 2011 Oct 12. PubMed PMID: 22019934.

25. Rojo-Vazquez, F. A., Pardo-Lledias, J., Francos-Von Hunefeld, M., CorderoSanchez, M., Alamo-Sanz, R., Hernandez-Gonzalez, A., Brunetti, E., Siles-Lucas, M. 2011. Cystic echinococcosis in Spain: current situation and relevance for other endemic areas in Europe. PLoS Negl Trop Dis. Jan 25; 5(1): e893. doi: 10.1371/journal.pntd.0000893. Review. PubMed PMID: 21283615; PubMed Central PMCID: PMC3026768.

26. Brundu, D., Piseddu, T., Stegel, G., Masu, G., Ledda, S., Masala, G. 2014. Retrospective study of human cystic echinococcosis in Italy based on the analysis of hospital discharge records between 2001 and 2012. Acta Trop. Dec; 140: 9196. doi: 10.1016/j.actatropica.2014.08.011. Epub 2014 Aug 19. PubMed PMID: 25149351.

27. Ahmadi, N. A., Badi, F. 2011. Human hydatidosis in Tehran, Iran: a retrospective epidemiological study of surgical cases between 1999 and 2009 at two university medical centers. Trop Biomed. Aug; 28(2): 450-456. PubMed PMID: 22041768.

28. Gholami, S., Tanzifi, A., Sharif, M., Daryani, A., Rahimi, M. T., Mirshafiee, S., Sarvi, S. 2018. Demographic aspects of human hydatidosis in Iranian general population based on serology: A systematic review and meta-analysis. Vet World. Nov; 11(10): 1385-1396. doi: 10.14202/vetworld.2018.

29. Khan, A., Zahoor, S., Ahmed, H., Malik, U., Butt, R. A., Muzam, M. S., Kilinc, S. G., Noor, N., Zahoor, S., Afzal, M. S., Mansur, H., Irum, S., Simsek, S. 2018. A retrospective analysis on the cystic echinococcosis cases occured in Northeastern Punjab Province, Pakistan. Korean J Parasitol. Aug; 56(4): 385-390. doi: 10.3347/kjp.2018.56.4.385.

30. Botezatu, C., Mastalier, B., Patrascu, T. 2018. Hepatic hydatid cyst - diagnose and treatment algorithm. J Med Life. Jul-Sep; 11(3): 203-209. doi: 10.25122/jml2018-0045.

31. Jordanova, D. P., Harizanov, R. N., Kaftandjiev, I. T., Rainova, I. G., Kantardjiev, T. V. 2015. Cystic echinococcosis in Bulgaria 1996-2013, with emphasis on childhood infections. Eur J Clin Microbiol Infect Dis. Jul; 34(7): 1423-1428. doi: 10.1007/s10096-015-2368-z. Epub 2015 Apr 12. PubMed PMID: 25864190.

32. Dopchiz, M. C., Elissondo, M. C., Andresiuk, M. V., Maiorini, E., Gutiérrez, A. M., Muzulin, P. M., Rosenzvit, M. C., Lavallén, C. M., Denegri, G. 2009. Pediatric hydatidosis in the south-east of the Buenos Aires province, Argentina. 
Rev Argent Microbiol. Apr-Jun; 41(2): 105-111. PubMed PMID: 19623901.

33. Marcinkutè, A., Šarkūnas, M., Moks, E., Saarma, U., Jokelainen, P., Bagrade, G., Laivacuma, S., Strupas, K., Sokolovas, V., Deplazes, P. 2015. Echinococcus infections in the Baltic region. Vet Parasitol. Oct 30; 213(3-4): 121-131. doi: 10.1016/j.vetpar.2015.07.032. Epub 2015 Jul 31. Review. PubMed PMID: 26324242 .

34. Bakiri, A. H., Mingomataj, E. C. 2010. Parasites induced skin allergy: a strategic manipulation of the host immunity. J Clin Med Res. Dec 11; 2(6): 247-255. doi: 10.4021/jocmr456w. PubMed PMID: 22043257; PubMed Central PMCID: PMC3194028.

35. Siracusano, A., Teggi, A., Ortona, E. 2009. Human cystic echinococcosis: old problems and new perspectives. Interdiscip Perspect Infect Dis. 474368. doi: 10.1155/2009/474368. Epub 2009 Nov 1. PubMed PMID: 19888428; PubMed Central PMCID: PMC2771156.

36. Branci, S., Ewertsen, C., Thybo, S., Nielsen, H. V., Jensen, F., Wettergren, A., Larsen, P. N., Bygbjerg, I. C. 2012. Cystic echinococcosis of the liver: experience from a Danish tertiary reference center (2002-2010). J Travel Med. Jan-Feb; 19(1): 28-34. doi: 10.1111/j.1708-8305.2011.00577.x. Epub 2011 Dec 8. PubMed PMID: 22221809.

37. Fischer, P. R., Cabada, M. M., White, A. C. 2016. Textbook of Pediatrics, 20th Ed., Chapter 304, 1753-1756.e1. Elsevier, Inc.

38. Symeonidis, N., Pavlidis, T., Baltatzis, M., Ballas, K., Psarras, K., Marakis, G., Sakantamis, A. 2013. Complicated liver echinococcosis: 30 years of experience from an endemic area. Scand $J$ Surg. 102(3): 171-177. doi: 10.1177/1457496913491877. PubMed PMID: 23963031.

39. Stojkovic, M., Mickan, C., Weber, T. F., Junghanss, T. 2015. Pitfalls in diagnosis and treatment of alveolar echinococcosis: a sentinel case series. BMJ Open Gastroenterol. Jul 16; 2(1): e000036. doi: 10.1136/bmjgast-2015-000036. eCollection 2015. PubMed PMID: 26462284; PubMed Central PMCID: PMC4599161.

40. WHO Informal Working Group. 2003. International classification of ultrasound images in cystic echinococcosis for application in clinical and field epidemiological settings. Acta Trop. Feb; 85(2): 253-261. PubMed PMID: 12606104.

41. Liu, W., Delabrousse, É., Blagosklonov, O., Wang, J., Zeng, H., Jiang, Y., Wang, J., Qin, Y., Vuitton, D. A., Wen, H. 2014. Innovation in hepatic alveolar echinococcosis imaging: best use of old tools, and necessary evaluation of new ones. Parasite. 21:74. doi: 10.1051/parasite/2014072. Epub 2014 Dec 23. Review. PubMed PMID: 25531446; PubMed Central PMCID: PMC4273719

42. Kratzer, W., Gruener, B., Kaltenbach, T. E., Ansari-Bitzenberger, S., Kern, P., Fuchs, M., Mason, R. A., Barth, T. F., Haenle, M. M., Hillenbrand, A., Oeztuerk, S., Graeter, T. 2015. Proposal of an ultrasonographic classification for hepatic 
alveolar echinococcosis: Echinococcosis multilocularis Ulm classificationultrasound. World $J$ Gastroenterol. Nov 21; 21(43): 12392-12402. doi: 10.3748/wjg.v21.i43.12392. PubMed PMID: 26604646; PubMed Central PMCID: PMC4649122.

43. Agudelo Higuita, N. I., Brunetti, E., McCloskey, C. 2016. Cystic echinococcosis. J Clin Microbiol. Mar; 54(3): 518-523. doi: 10.1128/JCM.02420-15. Epub 2015 Dec 16. Review. PubMed PMID: 26677245; PubMed Central PMCID: PMC4767951.

44. Piarroux, M., Piarroux, R., Giorgi, R., Knapp, J., Bardonnet, K., Sudre, B., Watelet, J., Dumortier, J., Gérard, A., Beytout, J., Abergel, A., Mantion, G., Vuitton, D. A., Bresson-Hadni, S. 2011. Clinical features and evolution of alveolar echinococcosis in France from 1982 to 2007: results of a survey in 387 patients. $J$ Hepatol. Nov; 55(5): 1025-1033. doi: 10.1016/j.jhep.2011.02.018. Epub 2011 Feb 25. PubMed PMID: 21354448.

45. Wuestenberg, J., Gruener, B., Oeztuerk, S., Mason, R. A., Haenle, M. M., Graeter, T., Akinli, A. S., Kern, P., Kratzer, W. 2014. Diagnostics in cystic echinococcosis: serology versus ultrasonography. Turk J Gastroenterol. Aug; 25(4): 398-404. doi: 10.5152/tjg.2014.7112. PubMed PMID: 25254522.

46. Hemphill, A., Stadelmann, B., Rufener, R., Spiliotis, M., Boubaker, G., Müller, J., Müller, N., Gorgas, D., Gottstein, B. 2014. Treatment of echinococcosis: albendazole and mebendazole--what else? Parasite. 21:70. doi: 10.1051/parasite/2014073. Epub 2014 Dec 22. Review. PubMed PMID: 25526545; PubMed Central PMCID: PMC4271654.

47. Vuitton, D. A. 2009. Benzimidazoles for the treatment of cystic and alveolar echinococcosis: what is the consensus? Expert Rev Anti Infect Ther. Mar; 7(2): 145-149. doi: 10.1586/14787210.7.2.145. Review. PubMed PMID: 19254162.

48. Tamarozzi, F., Nicoletti, G. J., Neumayr, A., Brunetti, E. 2014. Acceptance of standardized ultrasound classification, use of albendazole, and long-term followup in clinical management of cystic echinococcosis: a systematic review. Curr Opin Infect Dis. Oct; 27(5): 425-431. doi: 10.1097/QCO.0000000000000093. Review. PubMed PMID: 25101556.

49. Steinmetz, S., Racloz, G., Stern, R., Dominguez, D., Al-Mayahi, M., Schibler, M., Lew, D., Hoffmeyer, P., Uçkay, I. 2014. Treatment challenges associated with bone echinococcosis. J Antimicrob Chemother. Mar; 69(3): 821-826. doi: 10.1093/jac/dkt429. Epub 2013 Nov 11. Review. PubMed PMID: 24222611.

50. Moroni, S., Moscatelli, G., Bournissen, F. G., González, N., Ballering, G., Freilij, H., Salgueiro, F., Altcheh, J. 2016. Abdominal cystic echinococcosis treated with albendazole. A Pediatric Cohort Study. PLoS One. Sep 2; 11(9): e0160472. doi: 10.1371/journal.pone.0160472. eCollection 2016. PubMed PMID: 27589236; PubMed Central PMCID: PMC5010188.

51. Nabarro, L. E., Amin, Z., Chiodini, P. L. 2015. Current management of cystic echinococcosis: a survey of specialist practice. Clin Infect Dis. Mar 1; 60(5): 
721-728. doi: 10.1093/cid/ciu931. Epub 2014 Nov 24. PubMed PMID: 25422388.

52. Nazligul, Y., Kucukazman, M., Akbulut, S. 2015. Role of chemotherapeutic agents in the management of cystic echinococcosis. Int Surg. Jan; 100(1): 112 114. doi: 10.9738/INTSURG-D-14-00068.1. Review. PubMed PMID: 25594649; PubMed Central PMCID: PMC4301274.

53. Stojkovic, M., Zwahlen, M., Teggi, A., Vutova, K., Cretu, C. M., Virdone, R. 2009. Treatment response of cystic echinococcosis to benzimidazoles: a systematic review. PLoS Negl Trop Dis. 3(9): e524.

54. Pang, N., Zhang, F., Ma, X., Zhang, Z., Zhao, H., Xin, Y., Wang, S., Zhu, Y., Wen, H., Ding, J. 2014. Th9/IL-9 profile in human echinococcosis: their involvement in immune response during infection by Echinococcus granulosus. Mediators Inflamm. 781649. doi: 10.1155/2014/781649. Epub 2014 Mar 30. PubMed PMID: 24799769; PubMed Central PMCID: PMC3985320.

55. Mourglia-Ettlin, G., Amezcua-Vesely, M. C., Fraga, R., Baz, A., Merino, M. C., Gruppi, A., Dematteis, S. 2011. Echinococcus granulosus glycoconjugates induce peritoneal B cell differentiation into antibody-secreting cells and cytokine production. Parasite Immunol. Nov; 33(11): 621-631. doi: 10.1111/j.13653024.2011.01326.x. PubMed PMID: 21992445.

56. Shan, J. Y., Ji, W. Z., Li, H. T., Tuxun, T., Lin, R. Y., Wen, H. 2011. TLR2 and TLR4 expression in peripheral blood mononuclear cells of patients with chronic cystic echinococcosis and its relationship with IL-10. Parasite Immunol. Dec; 33(12): 692-696. doi: 10.1111/j.1365-3024.2011.01335.x. PubMed PMID: 21923667.

57. Tuxun, T., Ma, H. Z., Apaer, S., Zhang, H., Aierken, A., Li, Y. P., Lin, R. Y., Zhao, J. M., Zhang, J. H., Wen, H. 2015. Expression of Toll-Like Receptors 2 and 4 and Related Cytokines in Patients with Hepatic Cystic and Alveolar Echinococcosis. Mediators Inflamm. 632760. doi: 10.1155/2015/632760. Epub 2015 Nov 9. PubMed PMID: 26635448; PubMed Central PMCID: PMC4655286.

58. Pan, W., Hao, W. T., Shen, Y. J., Li, X. Y., Wang, Y. J., Sun, F. F., Yin, J. H., Zhang, J., Tang, R. X., Cao, J. P., Zheng, K. Y. 2017. The excretory-secretory products of Echinococcus granulosus protoscoleces directly regulate the differentiation of B10, B17 and Th17 cells. Parasit Vectors. Jul 21; 10(1): 348. doi: 10.1186/s13071-017-2263-9. PubMed PMID: 28732522; PubMed Central PMCID: PMC5520350.

59. Wang, J., Vuitton, D. A., Müller, N., Hemphill, A., Spiliotis, M., Blagosklonov, O., Grandgirard, D., Leib, S. L., Shalev, I., Levy, G., Lu, X., Lin, R., Wen, H., Gottstein, B. 2015. Deletion of fibrinogen-like protein 2 (FGL-2), a novel CD4+ CD25+ Treg effector molecule, leads to improved control of Echinococcus multilocularis infection in Mice. PLoS Negl Trop Dis. May 8; 9(5): e0003755. doi: 10.1371/journal.pntd.0003755. eCollection 2015 May. PubMed PMID: 25955764; PubMed Central PMCID: PMC4425495.

60. Wang, H., Li, J., Pu, H., Hasan, B., Ma, J., Jones, M. K., Zheng, K., Zhang, X., 
Ma, H., McManus, D. P., Lin, R., Wen, H., Zhang, W. 2014. Echinococcus granulosus infection reduces airway inflammation of mice likely through enhancing IL-10 and down-regulation of IL-5 and IL-17A. Parasit Vectors. Nov 20; 7: 522. doi: 10.1186/s13071-014-0522-6. PubMedPMID: 25409540; PubMed Central PMCID: PMC4256745.

61. Hu, D., Song, X., Xie, Y., Zhong, X., Wang, N., Zheng, Y., Gu, X., Wang, T., Peng, X., Yang, G. 2015. Molecular insights into a tetraspanin in the hydatid tapeworm Echinococcus granulosus. Parasit Vectors. Jun 10; 8: 311. doi: 10.1186/s13071-015-0926-y. PubMed PMID: 26055542; PubMed Central PMCID: PMC4464875.

62. Naik, M. I., Tenguria, R. K., Haq, E. 2016. Detection of serum cytokines before and after pharmacological and surgical treatment in patients with cystic echinococcosis. $J$ Helminthol. Jan; 90(1): 91-95. doi: 10.1017/S0022149X15000085. Epub 2015 Mar 2. PubMed PMID: 25726962.

63. Amri, M., Mezioug, D., Touil-Boukoffa, C. 2009. Involvement of IL-10 and IL-4 in evasion strategies of Echinococcus granulosus to host immune response. Eur Cytokine Netw. Jun; 20(2): 63-68. doi: 10.1684/ecn.2009.0154. PubMed PMID: 19541591.

64. Petrone, L., Vanini, V., Amicosante, M., Corpolongo, A., Gomez Morales, M. A., Ludovisi, A., Ippolito, G., Pozio, E., Teggi, A., Goletti, D. A. 2017. T-cell diagnostic test for cystic echinococcosis based on antigen B peptides. Parasite Immunol. Dec; 39(12). doi: 10.1111/pim.12499. PubMed PMID: 29171068; PubMed Central PMCID: PMC5846893.

65. Akalin, S., Kutlu, S. S., Caylak, S. D., Onal, O., Kaya, S., Bozkurt, A. I. 2014. Seroprevalence of human cystic echinococcosis and risk factors in animal breeders in rural communities in Denizli, Turkey. J Infect Dev Ctries. Sep 12; 8(9): 11881194. doi: 10.3855/jidc.4343. PubMed PMID: 25212084.

66. Acosta-Jamett, G., Weitzel, T., Boufana, B., Adones, C., Bahamonde, A., Abarca, K., Craig, P. S., Reiter-Owona, I. 2014. Prevalence and risk factors for echinococcal infection in a rural area of northern Chile: a household-based crosssectional study. PLoS Negl Trop Dis. Aug 28; 8(8): e3090. doi: 10.1371/journal.pntd.0003090. eCollection 2014 Aug. PubMed PMID: 25167140; PubMed Central PMCID: PMC4148223.

67. Moro, P. L., Cavero, C. A., Tambini, M., Briceño, Y., Jiménez, R., Cabrera, L. 2008. Identification of risk factors for cystic echinococcosis in a peri-urban population of Peru. Trans R Soc Trop Med Hyg. Jan; 102(1): 75-78. Epub 2007 Oct 18. PubMed PMID: 17949765.

68. Larrieu, E. J., Costa, M. T., del Carpio, M., Moguillansky, S., Bianchi, G., Yadon, Z. E. 2002. A case-control study of the risk factors for cystic echinococcosis among the children of Rio Negro province, Argentina. Ann Trop Med Parasitol. Jan; 96(1): 43-52. PubMed PMID: 11989533.

69. Yuan R, Wu H, Zeng H, Liu P, Xu Q, Gao L, Li Y, Li R, Huang D, Yu C, Sun X. 
Prevalence of and risk factors for cystic echinococcosis among herding families in five provinces in western China: a cross-sectional study. Oncotarget. 2017 Sep 23; 8 (53):91568-91576. doi: 10.18632/oncotarget.21229.

70. Wang, Q., Huang, Y., Huang, L., Yu, W., He, W., Zhong, B., Li, W., Zeng, X., Vuitton, D. A., Giraudoux, P., Craig, P. S., Wu, W. 2014. Review of risk factors for human echinococcosis prevalence on the Qinghai-Tibet Plateau, China: a prospective for control options. Infect Dis Poverty. Jan 29; 3(1):3. doi: 10.1186/2049-9957-3-3. PubMed PMID: 24475907; PubMed Central PMCID: PMC3910240.

71. Harandi, M. F., Moazezi, S. S., Saba, M., Grimm, F., Kamyabi, H., Sheikhzadeh, F., Sharifi, I., Deplazes, P. 2011. Sonographical and serological survey of human cystic echinococcosis and analysis of risk factors associated with seroconversion in rural communities of Kerman, Iran. Zoonoses Public Health. Dec; 58(8): 582588. doi: 10.1111/j.1863-2378.2011.01407.x. Epub 2011 May 6. PubMed PMID: 21824361.

72. Akalin, S., Kutlu, S. S., Caylak, S. D., Onal, O., Kaya, S., Bozkurt, A. I. 2014. Seroprevalence of human cystic echinococcosis and risk factors in animal breeders in rural communities in Denizli, Turkey. J Infect Dev Ctries. Sep 12; 8(9): 11881194. doi: 10.3855/jidc.4343. PubMed PMID: 25212084.

73. Bingham, G. M., Budke, C. M., Larrieu, E., Del Carpio, M., Mujica, G., Slater, M. R., Moguillansky, S. 2014. A community-based study to examine the epidemiology of human cystic echinococcosis in Rio Negro Province, Argentina. Acta Trop. Aug; 136: 81-88. doi: 10.1016/j.actatropica.2014.04.005. Epub 2014 Apr 15. PubMed PMID: 24742907.

74. Haleem, S., Niaz, S., Qureshi, N. A., Ullah, R., Alsaid, M. S., Alqahtani, A. S., Shahat, A. A. 2018. Incidence, risk factors, and epidemiology of cystic echinococcosis: A complex socioecological emerging infectious disease in Khyber Pakhtunkhwa, province of Pakistan. Biomed Res Int. Sep 12; 2018: 5042430. doi: $10.1155 / 2018 / 5042430$.

75. Yang, Y. R., Sun, T., Li, Z., Zhang, J., Teng, J., Liu, X., Liu, R., Zhao, R., Jones, M. K., Wang, Y., Wen, H., Feng, X., Zhao, Q., Zhao, Y., Shi, D., Bartholomot, B., Vuitton, D. A., Pleydell, D., Giraudoux, P., Ito, A., Danson, M. F., Boufana, B., Craig, P. S., Williams, G. M., McManus, D. P. 2006. Community surveys and risk factor analysis of human alveolar and cystic echinococcosis in Ningxia Hui Autonomous Region, China. Bull World Health Organ. Sep; 84(9): 714-721. Erratum in: Bull World Health Organ. 2006 Oct;84(10):840. PubMed PMID: 17128341; PubMed Central PMCID: PMC2627473.

76. Li, D., Gao, Q., Liu, J., Feng, Y., Ning, W., Dong, Y., Tao, L., Li, J., Tian, X., Gu, J., Xin, D. 2015. Knowledge, attitude, and practices (KAP) and risk factors analysis related to cystic echinococcosis among residents in Tibetan communities, Xiahe County, Gansu Province, China. Acta Trop. Jul; 147: 17-22. doi: 10.1016/j.actatropica.2015.02.018. Epub 2015 Mar 7. PubMed PMID: 25757370; PubMed Central PMCID: PMC4441730 
77. Mosayebi, M., Dalimi Asl, A., Moazzeni, M., Mosayebi, G. 2013. Differential genomics output and susceptibility of Iranian patients with unilocular hydatidose. Iran J Parasitol. Oct; 8(4): 510-515. PubMed PMID: 25516730; PubMed Central PMCID: PMC4266113.

78. Lukmanova, G. I., Gumerov, A. A., Elicheva, Z. M., Lukmanova, L. I. 2011. Distribution of HLA specificity frequencies in patients with cystic echinococcosis. Med Parazitol (Mosk). Oct-Dec; (4):14-16. Russian. PubMed PMID: 22308705.

79. Chakhtoura, M., Al-Awar, G., Abdelnoor, A. M. 2007. Human leukocyte antigen (HLA) associations, antibody titers and circulating immune complexes in patients with cystic echinococcosis. Acta Parasitologica, 52(4), 414-418; ISSN 12302821.

80. Hussein, E. M., Al-Mohammed, H. I., Al-Mulhim, A. S., Aboulmagd, E. 2012. HLA class II DRB1 resistance and susceptible markers in hydatidosis Saudi patients in association to the clinical course and gender. J Egypt Soc Parasitol. Dec; 42(3): 573-582. PubMed PMID: 23469632.

81. Eiermann, T. H., Bettens, F., Tiberghien, P., Schmitz, K., Beurton, I., BressonHadni, S., Ammann, R. W., Goldmann, S. F., Vuitton, D. A., Gottstein, B., Kern, P. 1998. HLA and Alveolar Echinococcosis. Tissue Antigens. Aug; 52(2): 124129. PubMed PMID: 9756400. 


\section{PUBLIKĀCIJAS UN PREZENTĀCIJAS \\ PAR PĒTİJUMA TĒMU}

\section{Zinātniskie raksti (4)}

1. Laivacuma, S., Deksne, G., Jokelainen, P., Ivanovs, A., Zaharova, L., Zeltiña, I., Vīksna, L., Krūmiña, A. Risk Factors for Human Cystic Echinococcosis in Latvia. Vector Borne Zoonotic Dis. 2019 Feb 25. doi: 10.1089/vbz.2018.2354. [Epub ahead of print] PubMed PMID: 30801230.

2. Laivacuma, S., Eglīte, J., Derovs, A., Vīksna L. Distribution of HLA Allele Frequencies in Patients with Cystic and Alveolar Echinococcosis in Latvia. Proc. Latv. Acad. Sci. Sect. B nat. Exact appl. Sci. 2019; 73(4), pp. 296-303.

3. Laivacuma, S., Ivanovs, A., Derovs, A., Viksna, L. Cystic echinococcosis: epidemilogical and clinical aspects of Latvian population and review of the literature. Eksp Klin Gastroenterol. 2015; (7):24-30. Review. PubMed PMID: 26817119.

4. Marcinkutè, A., Šarkūnas, M., Moks, E., Saarma, U., Jokelainen, P., Bagrade, G., Laivacuma, S., Strupas, K., Sokolovas, V., Deplazes, P. Echinococcus infections in the Baltic region. Vet Parasitol. 2015 Oct 30; 213 (3-4): 121-31. doi: 10.1016/j.vetpar.2015.07.032. Epub 2015 Jul 31. Review. PubMed PMID: 26324242.

\section{Tēzes un prezentācijas starptautiskās konferencēs (5)}

1. Laivacuma, S., Zeltina, I. Echinococcus multilocularis infection of the liver: a clinical case. Collection of Scientific Papers 2017: Research articles in medicine \& pharmacy: Abstracts from VIII Latvian Gastroenterology 
Congress with International participation [Riga, Latvia, Dec.9, 2017] / Rīga Stradiņš University. - Rīga: RSU, 2018. - Suppl.1, p.40.

2. Laivacuma, S., Eglīte, J., Vīksna, L. Risk factors of echinococcosis in Latvia//7th Conference of the Scandinavian-Baltic Society for Parasitology (Riga, Latvia, June 8-9, 2017): [Abstracts]. - Riga, 2017. p.27.

3. Laivacuma, S., Eglite, J., Derovs, A., Viksna, L. Characteristics and HLA II class polymorphism in patients with alveolar echinococcosis in Latvia// Collection of Scientific Papers 2015: Research articles in medicine \& pharmacy: Abstracts from VII Latvian Gastroenterology Congress with International participation [Riga, Latvia, Dec.5, 2015]/Rīga Stradiņš University. - Rīga: RSU, 2016. Suppl.1, p.87.

4. Laivacuma, S., Krumina, A., Viksna, L. Pelvic bone and hip joint hydatid disease misdiagnosed as tuberculosis: a clinical case//Symposium "Innovation for the management of echinococcosis" (Besançon, France, Mar.27-29, 2014): [Abstracts]. - Besançon, 2014. p.154.

5. Laivacuma, S. Liver biochemical parameters in patients with liver echinococcosis//Collection of Scientific Papers 2013: Research articles in medicine \& pharmacy: Abstracts from VI Latvian Gastroenterology Congress with International participation (Riga, Latvia, Dec.7, 2013)/Riga Stradiņš University. - Riga, 2013. Suppl.1, p. 36.

\section{Tēzes un uzstāšanās Latvijas mēroga konferencēs (6)}

1. Laivacuma, S., Viksna, L. Specifisko antivielu titra izmaiņas kā ehinokokozes terapijas efektivitātes kritērijs. 2018. gada Zinātniskās konferences tēzes (Rīga, 2018.g. 22.-23.martā)/Rīgas Stradiņa universitāte. - Rīga, 2018. 12.lpp 
2. Laivacuma, S., Vīksna, L. Ehinokokozes slimnieku viedoklis par savu slimību// 2015.gada Zinātniskās konferences tēzes (Rīga, 2015.g. 26.27.martā)/Rīgas Stradiņa universitāte. - Rīga, 2015. 193. lpp.

3. Laivacuma, S., Vīksna, L. Ehinokokozes slimnieku viedoklis par savu slimību//2015.gada Zinātniskās konferences tēzes (Rīga, 2015.g. 26.27.martā) / Rīgas Stradiṇa universitāte. - Rīga, 2015. 193. lpp.

4. Laivacuma, S., Vīksna, L. Alveolārās ehinokokozes slimnieku analīze//2014.gada Zinātniskās konferences tēzes (Rīga, 2014.g. 10.11.aprīlī) / Rīgas Stradiña universitāte. - Rīga, 2014. 184. lpp.

5. Laivacuma, S., Vīksna, L. Ehinokokozes medikamentozās ārstēšanas rezultāti Latvijā//2013.gada Zinātniskās konferences tēzes (Rīga, 2013.g. 21.-22.martā)/Rīgas Stradiṇa universitāte. - Rīga, 2013. 195. lpp.

6. Vīksna, L., Aldiņš, P., Zeltiņa, I., Vilmanis, J., Laivacuma, S. Ehinokokozes diagnostikas un ārstēšanas taktika//2010.gada Zinātniskās konferences tēzes (Rīga, 2010.g. 18.-19.martā)/Rīgas Stradiņa universitāte. - Rīga, 2010. 194. lpp. 


\section{PATEICĪBAS}

Visdzil̄ākā pateicība par atsaucību darba tapšanā un ilgstošu nenogurstošu palīdzību darba zinātniskajiem vadītājiem profesorei Ludmilai Vīksnai un Andrejam Ivanovam.

Patiesa pateicība par atbalstu RSU Klīniskās imunologijas un imunoğenētikas starpkatedru laboratorijas darbiniekiem, īpaši Jel̦enai Eglītei un Oksanai Koḷesovai.

Paldies iesaistītajiem ǵimenes ārstiem, kuri neatteica atbalstu, meklējot pacientus pētījuma kontroles grupu izveidei!

Paldies par palīdzību RSU Infektologijas un dermatologijas katedras darbiniecei Dacei Bantauskai! 